\title{
KINERJA KARYAWAN PT. SBS
}

\author{
Yulandri $^{1}$ \\ ${ }^{1}$ Prodi Manajemen Universitas Muhammadiyah Bengkulu \\ ydri5005@gmail.com
}

\begin{abstract}
This study entitled The effect of compensation and work discipline on employee performance at PT (SBS) Sinar Bengkulu Selatan. The formulation of the problem in this study is whether the effect of compensation and work discipline on employee performance at PT (SBS) Sinar Bengkulu Selatan. . The purpose of this study was to determine the effect of work compensation and discipline on employee performance at PT (SBS) Sinar Bengkulu Selatan.

This research was conducted on the employees of PT (SBS) Sinar Bengkulu Selatan. While the time of this study was 20 days, from December 15 to January 5, 2020. The population of this study were employees at PT (SBS) Sinar Bengkulu Selatan, while the sample of this study were employees of PT (SBS) Sinar Bengkulu Selatan which amounted to 95 people. This means that the sample material uses quantitative methods.

With the research test data analysis technique, the results of the study can be concluded that the respondents' perceptions about Compensation Location (X1) and Work Discipline (X2) affect Employee Performance (Y) with the results of multiple linear regression obtained the following equation: $\mathrm{Y}=14,876+0,277 \mathrm{X} 1$ $+0.795 \mathrm{X} 2$ correlation analysis $\mathrm{R}=0.823(\mathrm{X} 1-\mathrm{Y}), 0.926(\mathrm{X} 2-\mathrm{Y})$ and the coefficient of detrmination of $\mathrm{R} 2=0.521$ or approximately $(52.51 \%)$ through hypothesis testing together (simultaneously) and individually (partial) in This study uses the f test and test, compensation (X1) and work discipline (X2), = 0.000 , it means that the value of fsig $<0.05$ shows that there is a significant influence together.
\end{abstract}

Keywords: Compensation and Work Discipline on Employee Performance. 


\section{BAB I \\ PENDAHULUAN}

\subsection{Latar Belakang}

Peranan Sumber Daya Manusia memiliki kedudukan yang sangat penting dan strategis di dalam organisasi untuk mencapai tujuan. Sumber daya manusia sangat penting bagi perusahaan dalam mengelola, mengatur, dan memanfaatkan karyawan, sehingga dapat berfungsi secara produktif untuk tercapainya tujuan perusahaan. Sumber Daya Manusia sebagai penggerak organisasi dalam mencapai tujuannya, maka upaya-upaya organisasi dalam mendorong karyawan untuk bekerja lebih baik harus terus dilakukan dengan adanya karyawan-karyawan yang bekerja secara baik ini, maka di harapkan hasil kerja (kinerja karyawan) yang baik juga tercapai oleh karyawan dalam melaksanakan tugasnya sesuai dengan tanggung jawab yang diberikan kepadanya.

Sumber daya manusia merupakan tokoh sentral dalam organisasi maupun perusahaan.Agar aktivitas manajemen berjalan dengan baik, perusahaan harus memiliki karyawan yang berpengetahuan dan berketrampilan tinggi serta usaha untuk mengelola perusahaan seoptimal mungkin sehingga kinerja karyawan meningkat.Menurut Budi Setiyawan dan Waridin (2006) kinerja karyawan merupakan hasil atau prestasi kerja karyawan yang dinilai dari segi kualitas maupun kuantitas berdasarkan standar kerja yang ditentukan oleh pihak organisasi.Kinerja yang baik adalah kinerja yang optimal, yaitu kinerja yang sesuai standar organisasi dan mendukung tercapainya tujuan organisasi.Organisasi yang baik adalah organisasi yang berusaha meningkatkan kemampuan sumber 
daya manusianya, karena hal tersebut merupakan faktor kunci untuk meningkatkan kinerja karyawan.

Peningkatan kinerja karyawan akan membawa kemajuan bagi perusahaan untuk dapat bertahan dalam suatu persaingan lingkungan bisnis yang tidak stabil. Oleh karena itu upaya-upaya untuk meningkatkan kinerja karyawan merupakan tantangan manajemen yang paling serius karena keberhasilan untuk mencapai tujuan dan kelangsungan hidup perusahaan tergantung pada kualitas kinerja sumber daya manusia yang ada didalamnya.

PT.(SBS) Sinar Bengkulu Selatan merupakan perusahaan yang bergerak dibidang agribisnis atau yang lebih tepatnya perusahaan tempat pengelolaan minyak mentah kelapa sawit. Perusahaan ini memiliki lahan sekitar 300 hektar kebun kelapa sawit perusahaan tersebut merupakan perusahaan yang didirikan pada tahun 2011.Kelebihan perusahaan ini adalah perusahaan ini berfokus pada pengeloalaan minyak mentah,sehingga buah kelapa sawit yang segar dapat dikelola dengan baik dengan perusahaan sehingga menghasilnya minyak mentah yang berkualitas.Perusahaan ini dipilih karena memiliki jarak yang tidak terlalu jauh dengan alamat penulis dan penulis banyak mendengar cerita dari karyawan yang bekerja diperusahaan ini. Perusahaan ini sepenuhnya milik perseorangan dan bertujuan untuk menghasilkan minyak mentah yang baik dan berkualitas yang selanjutnyaakan dikirim pabrik pusatuntuk dikelola menjadi minyak jadi. Apabila dilihat dari produktifitasnya, perusahaan ini sudah cukup terbilang baik hanya saja masih terdapat beberapa kekurangan yang terjadi di dalamnya.Dari informasi yang diperoleh dari karyawan PT.(SBS) Sinar Bengkulu Selatan, dapat diketahui 
bahwa kinerja karyawan pada perusahaan ini masih memiliki beberapa kelemahan antara lain karyawan disini masih kurangnya pemberiankompensansi yang diberikan kepada karyawan,kurangnyadisiplin waktu, bisa menyebabkan kinerja karyawan tersebut sangat rendah.

Kinerja karyawan yang tinggi sangatlah diharapkan oleh perusahaan terserbut. Semakin banyak karyawan yang mempunyai kinerja tinggi, maka produktivitas perusahaan secara keseluruhan akan meningkat sehingga perusahaan akan dapat bertahan dalam persaingan global.

Karyawan dituntut untuk mampu menyelesaikan tugas dan tanggung jawabnya secara efektif dan efisien.Keberhasilan karyawan dapat diukur melalui kepuasan konsumen, berkurangnya jumlah keluhan dan tercapainya target yang optimal.Kinerja karyawan PT.(SBS) Sinar bengkulu selatan juga dapat diukur melalui penyelesaian tugasnya secara efektif dan efisien serta melakukan peran dan fungsinya dan itu semua berhubungan linear dan berhubungan positif bagi keberhasilan suatu perusahaan.

Terdapat faktor negatif yang dapat menurunkan kinerja karyawan, diantaranya adalah menurunnya keinginan karyawan untuk mencapai prestasi kerja, kurangnya ketepatan waktu dalam penyelesaian pekerjaan sehingga kurang menaati peraturan, pengaruh yang berasal dari lingkungannya, teman sekerja yang juga menurun semangatnya dan tidak adanya contoh yang harus dijadikan acuan dalam pencapaian prestasi kerja yang baik. Semua itu merupakan sebab menurunya kinerja karyawan dalam bekerja.Faktor-faktor yang dapat digunakan untuk meningkatkan kinerja diantaranya adalah kompensansi dan disiplin kerja. 
Kompensasi merupakan segala sesuatu yang diterima oleh para karyawan sebagai balas jasa untuk kerja mereka. Setiap perusahaan memiliki perbedaan sistem kompensasi, sistem disesuaikan dengan visi, misi, dan tujuannya. Menurut Simamora (1997), kompensasi terdiri dari Kompensasi Finansial (bayaran pokok, bayaran prestasi, bayaran insentif, bayaran tertangguh, program perlindungan, bayaran diluar jam kerja, fasilitas) dan Kompensasi Nonfinansial (pekerjaan dan lingkungan kerja). Kompensasi yang sesuai dengan keinginan karyawan atas pekerjaannya dapat memacu semangat karyawan untuk bekerja lebih baik dari waktu ke waktu, sehingga memberikan pengaruh positif bagi peningkatan hasil kerja karyawan (Asmawi, M, 2017, Onsardi, 2018). Kepuasan terhadap besarnya kompensasi merupakan elemen utama terciptanya kepuasan kerja. Selain itu, kepuasan kompensasi juga berperan membentuk sikap seorang karyawan dalam bekerja (Firmandari, 2014).Berdasarkan teori tersebut maka dapat diketahui bahwa kompensansi berperan penting di dalam sebuah perusahaan.dengan adanya kompensansi ,karyawan bisa memenuhi semua kebutuhanya serta berdampak baik pula pada kinerja karyawan.

Pemberian kompensasi merupakan salah satu pelaksanaan fungsi manajemen sumber daya manusia yang berhubungan dengan semua jenis pemberian penghargaan individual sebagai pertukaran dalam melaksanakan tugas keorganisasian. Pemberian kompensasi haruslah adil dan layak bagi seorang karyawan. Artinya adil dan layak adalah bahwa sedapat mungkin kompensasi atau gaji yang diterima kelangsungan hidup karyawan dan pemberian kompensasi itu harus pula berdasarkan pada dasar kecilnya tanggung jawab dan risiko dari 
masing-masing pekerjaan sehingga dapat meningkatkan kinerja karyawan (Keraf, 2000; Tangkilisan, 2005; Tanjung, 2005; Yayu, n.d.).

Menurut Umar (2007:16) dan Onsardi (2018), kompensasi adalah segala sesuatu yang diterima oleh pegawai berupa gaji, upah, insentif, bonus, premi, pengobatan, asuransi dan lain-lain yang sejenis yang di bayar langsung perusahaan

Selain kompensasi, ada juga disiplin kerja yang mempengaruhi kinerja perusahaan. Disiplin kerja merupakan faktor yang dapat mempengaruhi kinerja karyawan, menurut Mangkuprawira (2007), bahwa disiplin kerja sangat mempengaruhi kinerja karyawan, hal ini disebabkan karena disiplin merupakan bentuk-bentuk latihan bagi karyawan dalam melaksanakan aturan-aturan perusahaan. Semakin disiplin karyawan semakin tinggi produktivitas kerja karyawan dan kinerja perusahaan.

Menurut Rivai (2003), disiplin kerja adalah suatu alat yang digunakan para manajer untuk berkomunikasi dengan karyawan agar mereka bersedia untuk mengubah sesuatu perilaku serta sebagai suatu upaya untuk meningkatkan kesadaran dan kesediaan seseorang menaati semua peraturan perusahaan dan norma-norma sosial yang berlaku. Disiplin kerja pada karyawan sangat dibutuhkan, karena apa yang menjadi tujuan organisasi akan sukar dicapai bila tidak ada disiplin kerja. Kedisiplinan merupakan fungsi operatif manajemen sumber daya manusia yang terpenting karena semakin baik disiplin pegawai, semakin tinggi prestasi kerja yang dapat dicapainya. Tanpa disiplin pegawai yang baik, sulit bagi organisasi mencapai hasil yang optimal (Sedarmayanti dala, 
2015).Sebagaimana pendapat dimaksud dapat disimpulkan bahwa disiplin kerja adalah suatu keadaan tertib dimana seseorang atau sekelompok orang yang tergabung dalam organisasi tersebut berkehendak mematuhi dan menjalankan peraturan peraturan perusahaan baik yang tertulis maupun tidak tertulis dengan dilandasi kesadaran dan keinsyafan akan tercapainya suatu kondisi antara keinginan dan kenyataan dan diharapkan agar para karyawan memiliki sikap disiplin yang tinggi dalam bekerja sehingga produktivitasnya meningkat. Oleh karena itu, peningkatan kinerja karyawan dapat dilakukan dengan memberikan kompensasi yang sebanding dengan apa yang karyawan lakukan terhadap perusahaan, selain itu disiplin kerja karyawan yang baik juga akan mempengaruhi kinerja karyawan. Kualiatas sumber daya manusia merupakan salah satu faktor untuk meningkatkan kinerja karyawan di dalam perusahaan. Dan juga di perlukan sumber daya manusia yang mempunyai disiplin kerja tinggi dan perusahaan dapat mengapresiasi kinerja karyawan dengan memberikan kompensasi yang sebanding akan dapat mendukung peningkatan kinerja karyawan.

Menurut Budi Setiyawan dan Waridin (2006), disiplin kerja sebagai keadaan ideal dalam mendukung pelaksanaan tugas sesuai aturan dalam rangka mendukung optimalisasi kerja. Salah satu syarat agar disiplin dapat ditumbuhkan dalam lingkungan kerja ialah, adanya pembagian kerja yang tuntas sampai kepada pegawai atau petugas yang paling bawah, sehingga setiap orang tahu dengan sadar apa tugasnya, bagaimana melakukannya, kapan pekerjaan dimulai dan selesai, seperti apa hasil kerja yang disyaratkan, dan kepada siapa mempertanggung jawabkan hasil pekerjaan itu (Budi Setiyawan dan Waridin, 2006). 
Disiplin kerja seperti tujuan dan kemampuan, balas jasa, sanksi hukum, ketegasan serta hubungan kemanusiaan dan kompensasi seperti gaji, bonus dan tunjangan bagi karyawan berprestasi. Disiplin kerja merupakan suatu sikap menghormati, patuh dan taat pada peraturan-peraturan yang berlaku. Disiplin kerja sangat penting karena dengan karyawan yang mempunyai disiplin kerja maka akan menghasilkan kualitas kerja, kuantitas kerja dan waktu kerja yang baik sehingga dapat meningkatkan kinerja karyawan. Kompensasi merupakan sesuatu yang diterima karyawan sebagai pengganti kontribusi jasa mereka pada perusahaan (Baharuddin, Alhabsji, \& Utami, 2013).

Berdasarkan survei lapangan, peneliti menemukan adanya kekurangan menaati tata tertib, ketentuan-ketentuan perusahaan yang telah di tetapkan pihak perusahaan tetapi masih terjadi pada karaywan PT.(SBS) Sinar Bengkulu Selatan, seperti

1. Masih banyak karyawan yang mangkir kerja dengan berbagai alasan.

2. Masih banyak di temui karyawan yang berkeliaran pada saat jam kerja.

3. Tingkat keterlambatan karyawan yang cukup tinggi.

\section{Tabel 1.1}

Rekap absensi

Rekap absensi karyawan PT.(SBS) Sinar Bengkulu Selatan pada bulan Agustus sampai dengan bulan Oktober 2019

\begin{tabular}{|l|l|l|l|l|}
\hline Bulan & Izin & Sakit & Alpa & Jumlah \\
\hline Agustus & 10 orang & 3 orang & 20 orang & 43 orang \\
\hline September & 7 orang & 1 orang & 23 orang & 15 orang \\
\hline Oktober & 15 orang & 4 orang & 15 orang & 30 orang \\
\hline
\end{tabular}

Sumber : Manajemen Personalia PT.(SBS) Sinar Bengkulu selatan 2019. 
Hasil dari data tersebut menunjukkan bahwa tingkat kedisplinan karyawan pada PT.(SBS) SinarBengkulu Selatan masih perlu diperbaiki terlihat pada bulan agustus sebanyak 10 orang izin 3 orang sakit dan 20 orang alfa menunjukan bahwa tingkat kedisplinan karyawan di PT.(SBS) Sinar Bengkulu Selatan sangtlah rendah sehingga menyebabkan kinerja karyawan yang ada di PT.(SBS) Sinar Bengkulu Selatan turun. pada bulan september tingkat absensi karyawan PT.(SBS) Sinar Bengkulu Selatan menurun 7orang izin 1 orang sakit dan 23 orang alfa sehingga tingkat kedisplinan karyawan PT.(SBS) Sinar Bengkulu Selatan meningkat dibandingkan dengan bulan agustus yang lalu. Sedangkan pada oktober 15 orang izin 4 orang sakit dan 15 orang alfa sehingga tingkat kinerja karyawan kembali rendah di bulan oktober di lihat dari absensi karyawan pada bulan oktober sehingga suatu perusahaan untuk mencapai tujuan sulit untuk tercapai. Jika di lihat dari absensi karyawan tersebut bahwa kinerja karyawan sangatlah menurun karena sudah melanggar aturan perusahaan yang di telah di tetapkan oleh pihak perusahaan.

Menurut penelitian terdahulu :

Ananta Dwikristianto Satedjo dan Sesilya Kempa, (2015), Pengaruh Kompensansi dan Displin Kerja Terhadap Kinerja Karyawan PT. ModernWidya Tehnical Cabang Jayapura. Hasil penelitian menunjukan bahwa kompensasi berpengaruh signifikan terhadap kinerja karyawan. Disiplin kerja tidak berpengaruh signifikan terhadap kinerja karyawan. Sementara itu variabel kompensasi dan disiplin kerja berpengaruh signifikan terhadap kinerja karyawan PT. Modern Widya Tehnical Cabang Jayapura . 
Andi Armansyah, Idris Azis , Niluh Putu Evvy Rossanty,(2018), Pengaruh Kompensansi dan Displin Kerja Terhadap Kinerja Pegawai Kantor BPJS Kesehatan Cabang Palu.Hasil penelitian ini menunjukkan bahwa secara simultan kompensasi dan disiplin kerja berpengaruh signifikan terhadap Kinerja Pegawai Kantor BPJS Kesehatan Cabang Palu.Dan secara parsial kompensasi dan disiplin kerja berpengaruh signifikan terhadap kinerja pegawai Kantor BPJS Kesehatan Cabang Palu.

Ali Wairooy, (2017), Pengaruh Disiplin Kerja dan Kompensasi Terhadap Kinerja Karyawan pada PT. Pertamina (Persero), Tbk. Pemasaran Region VII Makassar.Hasil penelitian menunjukkan bahwa disiplin kerja berpengaruh positif dan signifikan terhadap kinerja karyawan, kompensasi berpengaruh positif dan signifikan terhadap kinerja karyawan dan disiplin kerja dan kompensasi secara simultan berpengaruh positif dan signifikan terhadap kinarja karyawan. Hal ini berarti ketika disiplin kerja dan kompensasi tinggi maka kinerja karyawan akan meningkat.

Berdasarkan hasil penelitian terdahulu yang menunjukan hasil yang berbeda-beda maka penulis tertarik untuk mengadakan penelitian lebih lanjut dalam penelitian ini yang akan mengangkat judul "Pengaruh Kompensansi Dan Displin Kerja Terhadap Kinerja Karyawan Pada PT. SBS Bengkulu Selatan.”

\subsection{Identifikasi Masalah}

Berdasarkan latar belakang yang telah diuraikan diatas, maka dapat diidentifikasi permasalahan yang ada, yaitu antara lain: 
1. Menurunnya kinerja karyawan pada PT.(SBS) Sinar Bengkulu Selatan terlihat dari turunnya pelayan karyawan terhadap konsumen.

2. Kurang kondusifnya displin kerja yang ada, terlihat dari hasil wawancara dengan karyawan pada PT.(SBS) Sinar Bengkulu Selatan.

3. Kurangnya kompensasi yang didapatkan jika dibandingkan dengan tugas yang ada.

4. Karyawan kurang puas dengan kompensasi yang mereka terima.

\subsection{Batasan Masalah}

Dalam penelitian ini sebenarnya banyak hal yang dapat diangkat dalam penelitian, namun penulis perlu membatasi masalah yang lebih terperinci dan jelas agar pembahasan dalam penelitian ini tidak terlalu meluas. Adapun batasan dalam penelitian ini adalah pengaruhkompensansi dan disiplin kerja terhadap kinerja karyawan.

\subsection{Rumusan Masalah}

1. Apakah kompensansi berpengaruh positif dan signifikan terhadap kinerja karyawan pada PT.(SBS) SinarBengkulu Selatan?

2. Apakah disiplin kerja berpengaruh positif dan signifikan terhadap kinerja karyawan pada PT.(SBS) SinarBengkulu Selatan?

3. Apakah kompensansi dan displin kerja berpengaruh positif dan signifikan terhadap kinerja karyawan pada PT.(SBS) Sinar Bengkulu Selatan? 


\subsection{Tujuan Penelitian}

Maksud dari penelitian ini adalah untuk memperoleh gambaran yang mendalam dan memberikan bukti empiris mengenai pengaruh kompensansi dan disiplin kerja terhadap kinerja karyawan. Berdasarkan latar belakang dan rumusan masalah yang ada, maka penelitian ini dilakukan dengan tujuan:

1. Untuk mengetahui pengaruh variabel kompensansi terhadap kinerja karyawan.

2. Untuk mengetahui pengaruh variabel disiplin kerja terhadap kinerja karyawan.

3. Untuk mengetahui pengaruh variabel kompensansi dan disiplin kerja terhadap kinerja karyawan.

\subsection{Manfaat Penelitian}

Manfaat-manfaat yang diharapkan dari penelitian ini adalah sebagai berikut:

1. Bagi penulis

Dapat menambah pengetahuan sebagai bekal dalam menerapkan ilmu yang telah diperoleh dibangku kuliah dalam dunia kerja yang sesungguhnya.

2. Bagi perusahaan

Diharapkan hasil penelitian ini dapat memberikan informasi yang berharga bagi perusahaan dalam pengelolaan SDM beserta segala kebijakan yang berkaitan langsung dengan aspek-aspek SDM secara lebih baik.

3. Bagi Pembaca

Hasil dari penelitian ini diharapkan dapat menambah informasi dan referensi bacaan bagi semua pihak yang membutuhkannya. 


\section{BAB II \\ STUDI PUSTAKA}

\subsection{Deskripsi Konseptual}

\subsubsection{Kinerja Karyawan}

Kinerja karyawan merupakan suatu yang dinilai dari apa yang dilakukan oleh seorang karyawan. Dalam kerjanya dengan kata lain, kinerja individu adalah bagaimana seorang karyawan melaksanakan pekerjaannya atau untuk kerjanya. Kinerja karyawan yang meningkat akan turut mempengaruhi atau meningkatkan prestasi organisasi sehingga tujuan organisasi yang telah ditentukan dapat dicapai (Onsardi, 2019, Anjani, R., 2019). Menurut Mangkunegara (2010), mendefinisikan Kinerja karyawan (prestasi kerja) adalah hasil secara kualitas dan kuantitas yang dicapai oleh seseorang karyawan dalam melaksanakan tugasnya sesuai dengan tanggung jawab yang diberikan kepadanya.

Menurut Budi Setiyawan dan Waridin (2006) kinerja karyawan merupakan hasil atau prestasi kerja karyawan yang nilai dari segi kualitas maupun kuantitas berdasarkan standar kerja yang ditentukan oleh pihak organisasi. Kinerja yang baik adalah kinerja yang optimal, yaitu kinerja yang sesuai standar organisasi dan mendukung tercapainya tujuan organisasi.

Keberhasilan suatu perusahaan sangat dipengaruhi oleh kinerja karyawannya (Brahmasari \& Suprayetno, 2009; Devi, 2009; Suwati, 2013; Thoyib, 2005, Onsardi, 2020). Setiap perusahaan akan selalu berusaha untuk meningkatkan kinerja karyawannya, dengan harapan apa yang menjadi tujuan 
perusahaan akan tercapai. Bila suatu perusahaan mampu meningkatkan kinerja karyawannya, maka perusahaan akan memperoleh banyak keuntungan.

Menurut Rivai (2008), kinerja merupakan suatu fungsi dari motivasi dan kemampuan untuk menyelesaikan tugas atau pekerjaan seseorang sepatutnya memiliki derajat kesediaan dan tingkat kemampuan tertentu.

Pengertian kinerja karyawan dari berbagai ahli diatas dapat disimpulkan bahwaKinerja merupakan suatu yang dinilai dari apa yang dilakukan oleh seorang karyawan Dalam kerjanya dengan kata lain, kinerja individu adalah bagaimana seorang karyawan melaksanakan pekerjaannya atau untuk kerjanya.

\subsubsection{Penilaian Kinerja}

Definisi kinerja yang dikemukakan para ahlipun berbeda-beda,menurut Mangkunegara (2001) dan Putri, S.H., (2020) kinerja merupakan hasil kerja secara kualitas dan kuantitas yang dicapai seseorang karyawan dalam melaksanakan tugasnya sesuai tanggung jawabnya.

Simamora (2004), menyatakan bahwa penilaian kinerja tidak dipahami secara sempit,tetapi dapat menghasilkan beranekan ragam jenis kinerja yang di ukur melalui berbagai cara. Kuncinya adalah dengan sering mengukur kinerja dan menggunakan informasi tersebut untuk koreksi pertengahan periode kinerja karyawan sesungguhnya dinilai atas lima dimensi, yaitu: mutu, kuantitas, penyelesaian proyek, kerjasama, dan kepemimpinan.

Penilaian kinerja menurut Werther dan Davis (1996: 324) mempunyai beberapa tujuan dan manfaat bagi organisasi dan pegawai yang di nilai, yaitu: 
1. Performance Improvement yaitu memungkinkan pegawai dan manajer untuk mengambil tindakan yang berhubungan dengan peningkatan kinerja.

2. Compensation Adjustment yaitu membantu para pengambil para keputusan untuk menetukan siapa saja yang berhak menerima kenaikan gaji atau sebaiknya.

3. Placement Decision yaitumenentukan promosi, transfer dan demosi.

4. Training and Development Needs yaitu mengevaluasi kebutuhan pelatihan dan pengembangan bagi pegawai agar kinerja mereka lebih optimal.

5. Career Planning and Development yaitu memandu untuk menentukan jenis karir dan potensi karir yang dapat di capai.

6. Staffing Process Deficiencies yaitu memengaruhi prosedur perekrutan pegawai.

7. Informational Innacurracies and Job Design Erors yaitu membantu menjelaskan apa saja kesalahan yang telah terjadi dalam MSDM terutama di bidang informasi job analysis, job design dan sistem informasi MSDM.

8. Equal Employement Opportunity yaitu menujukan bahwa placement decisions tidak diskrimintaif.

9. External Challenges, terkadang kinerja dipengaruhi oleh faktor eksternal seperti keluarga, keuangan pribadi, kesehatan dan lainya.biasanya faktor ini tidak terlalu terlihat namun dengan melakukan penilaian kinerja akan terlihat namun dengan melakukan penilaian kinerja akan terlihat sehingga membantu manajer SDMuntuk meningkatkan kinerja pegawai.

10. Feedback, yaitu memberikan umpanan balik bagi urusan kepegawaian maupun bagi karyawan itu sendiri. 
Sedangkan Agus Dharma (2004), mengatakan hampir semua cara

Halpengukuran kinerja mempertimbangkan hal-hal sebagai berikut:

1. Kuantintas yaitu jumlah yang harus diselesaikan atau dicapai.pengukuran kuantitatif melibatkan perhitungan keluaran dari proses atau pelaksanaan kegiatan.ini berkaitan dengan jumlah keluaran yang dihasilkan.

2. Kualitas yaitu mutu yang harus dihasilkan (baik dan tidaknya).pengukuran kualitatif mencerminkan pengukuran tingkat kepuasan yaitu seberapa baik penyelesaian. Ini berkaitan dengan bentuk keluaran.

3. Ketepatan waktu yaitu sesuai tidaknya dengan waktu yang direncanakan.pengukuran ketepatan waktu merupakan jenis khusus dari pengukuran kuantitatif yang menentukan ketepatan waktu penyelesaian suatu kegiatan. kinerja dapat dinilai dari apa yang yang dilakukan karyawan oleh seorang karyawan dalam kerjanya.tidak semua kriteria pengukuran kinerja karyawan tetapi hal ini harus di sesuaikan dengan jenis pekerjaan. Untuk menentukan apakah seorang karyawan memilkikinerja yang efektif atau tidak, perlu dikaji lebih dalam tentang faktor-faktor yang mempengaruhi kinerja.apabila pengkajian terhadap faktor yeng berpengaruh tersebut dapat mengeliminasi kinerja seorang karyawan yang tidak efektif.

\subsubsection{Karakteristik Kinerja Karyawan}

Karakteristik orang yang mempunyai kinerja tinggi oleh Mangkunegara (2004) sebagai berikut :

1. Memiliki tanggung jawab pribadi yang tinggi

2. Berani mengambil dan menanggung resiko yang dihadapi. 
3. Memilki tujuan yang realistis.

4. Memilki rencana kerja yang menyeluruh dan berjuang untuk merealisasi tujuanya.

5. Memanfaatkan umpan balik (fedd back) yang konkrit dalam seluruh kegiatan kerja yang di lakukan.

6. Mencari kesempatan untuk merealisasikan rencana yang telah diprogramkan.

\subsubsection{Indikator-indikator Kinerja Karyawan}

Menurut Mangkunegara (2009), indikator dari kinerja adalah

1. Kualitas, Seberapa baik seorang karyawan mengerjakan apa yangseharusnya dikerjakan.

2. Kuantitas, Seberapa lama seorang pegawai bekerja dalam satu harinya. Kuantitas kerja ini dapat dilihat dari kecepatan kerja setiap pegawai itu masingmasing.

3. Pelaksanaan Tugas, Seberapa jauh karyawan mampu melakukan pekerjaannya dengan akurat atau tidak ada kesalahan.

4. Tanggung jawab, Kesadaran akan kewajiban karyawan untuk melaksanakan pekerjaan yang diberikan perusahaan.

Menurut Suwondo dan Sutanto(2015) penilaian kinerja dapat diukur dengan:

1. Ketepatan dalam menyelesaikan pekerjaan, yaitu ketelitian dalam menyelesaikan pekerjaan, perhatian pada kualitas dalam penyelesaian pekerjaan, kemampuan memenuhi target perusahaan dan kemampuan menyelesaikan pekerjaan dengan tepat waktu. 
2. Tingkat inisiatif dalam bekerja, antara lainkemampuan mengantisipasi masalah yang mungkin terjadi dan kemampuan untuk membuat solusi alternatif bagi masalah tersebut.

3. Kecekatan mental, kecekatan mental diukur melalui kemampuan karyawan dalam memahami arahan yang diberikan oleh pemimpin dan kemampuan karyawan untuk bekerjasama dengan rekan kerja lain.

4. Kedisiplinan waktu dan absensi, merupakan tingkat ketepatan waktu dan tingkat kehadiran karyawan di tempat kerja.

Menurut Robbins (2006) menyatakan indikator kinerja karyawan, yaitu

1. Kualitas. Kualitas kerja diukur dari persepsi karyawan terhadap kualitas pekerjaan yang dihasilkan serta kesempurnaan tugas terhadap keterampilan dan kemampuan karyawan.

2. Kuantitas. Merupakan jumlah yang dihasilkan dinyatakan dalam istilah seperti jumlah unit, jumlah siklus aktivitas yang diselesaikan.

3. Ketepatan Waktu. Merupakan tingkat aktivitas diselesaikan pada awal waktu yang dinyatakan, dilihat dari sudut koordinasi dengan hasil output serta memaksimalkan waktu yang tersedia untuk aktivitas lain.

4. Efektivitas. Merupakan tingkat penggunaan sumber daya organisasi (tenaga, uang, teknologi, bahan baku) dimaksimalkan dengan maksud menaikkan hasil dari setiap unit dalam penggunaan sumber daya.

5. Kemandirian. Merupakan tingkat seseorang karyawan yang nantinya akan dapat menjalankan tugas kerjanya. 
6. Komitmen kerja. Merupakan suatu tingkat dimana karyawan mempunyai komitme kerja dengan instansi dan tanggung jawab karyawan terhadap kantor.

7. Disiplin kerja. Yaitu mentaati dan melaksankan pekerjaan berdasarkan tugas yang dibebankan kepada karyawan yang bersangkutan (Onsardi, 2020).

Dari 3 ahli yang dirujuk, maka peneliti menggunakan indikator dari, kinerja karyawan menurut Mangkunegara (2009), adalah "hasil kerja secara kualitas dan kuantitas yang dicapai oleh seorang karyawan dalam melaksanakan tugasnya sesuai dengan tanggung jawab yang diberikan kepadanya.

\subsubsection{Kompensansi}

Kompensansi merupakan bentuk balas jasa untuk karyawan yang di berikan oleh perusahaan (Onsardi, 2018). Lebih lanjut menurut Rivai (2003) kompensasi lasngsung terdiri dari pembayaran karyawan dalam bentuk upah, gaji, bonus atau komisi. Kompensasi langsung disebut upah dasar yakni upah atau gaji tetap yang seorang pekerja dalam bentuk upah bulanan (salary) atau upah mingguan atau upah tiap jam dalam bekerja (hourly wage)".

Hal ini sesuai pernyataan Mangkunegara (2013:85-86) bahwa ada dua bentuk kompensasi yaitu: (a) Upah dan Gaji. Upah adalah pembayaran berupa uang untuk pelayanan kerja atau uang yang biasanya dibayarkan kepada secara per jam, per hari, per setengah hari.Sedangkan gaji merupakan uang yang dibayarkan kepada atas jasa pelayanannya yang diberikan secara bulanan.Prinsip upah dan gaji, yaitu tingkat bayaran, struktur bayaran, menentukan bayaran secara individu, metode pembayaran, dan kontrol pembayaran. 
Tingkat bayaran bisa diberikan tinggi, rata-rata atau rendah bergantung pada kondisi perusahaan.Artinya, tingkat pembayaran bergantung pada kemampuan perusahaan membayar jasa nya.

Menurut Handoko dalam Eddy Sutrisno (2011:183-184) dimensi kompensasi meliputi kompensasi langsung dan tidak langsung yaitu: (a) Kompensasi langsung meliputi: gaji/upah dan insentif. (b) Kompensasi tidak langsung meliputi : fasilitas kantor, asuransi, transportasiwaktu dan tingkat kehadiran karyawan di tempat kerja.

Kompensasi merupakan hal yang sensitif bila dikaitkan dengan kelayakan dalam memenuhi kebutuhan, apalagi semakin besarnya tingkat kebutuhan saat ini sehingga gaji yang diberikan masih dirasa kurang cukup. Pemberian kompensasi yang makin baik akan mendorong karyawan untuk bekerja dengan makin baik dan produktif (Hasibuan, 2012:118)

Menurut para ahli diatas dapat di simpulkan bahwakompensansi adalah sikap karyawan yang merasa senang atas besarnya jumlah imbalan,baik dalam bentuk finansial maupun non finansial sebagai balas jasa untuk kerja mereka.

\subsubsection{Tujuan pemberian kompensansi}

Kompensansi yang diberikan bertujuan untuk meningkatkan motivasi serta menciptakan keinginan dan semangat karyawan dalam bekerja (Notoadmojo dalam Tohardi 2002:414) yaitu

1. Menghargai prestasi kerja

Dengan penghargaan organisasi terhadap prestasi kerja para karyawan, dengan selanjutnya akan mendorong perilaku-perilaku atau performa 
karyawan sesuai dengan apa yang diinginkan oleh organisasi atau perusahaan misalnya produktivitas yang tinggi.

2. Keadilan

Dengan adanya sistem kompensansi yang baik akan menjamin terjadinya keadilan diantara karyawan dan organisasi.masing-masing karyawan akan memperoleh imbalan yang sesuai dengan tujuan ,fungsi, jabatan, dan prestasi kerja.

3. Mempertahankan karyawan

Dengan sistem kompensansi yang baik para karyawan akan lebih baik betah bekerja pada organisasi itu, berarti mencegah keluarnya karyawan dari organisasi itu untuk mencari pekerjaan yang lebih menguntungkan.

4. Memperoleh karyawan yang bermutu

Dengan sistem kompensansi yang baik akan menarik lebih banyak calon karyawan, dengan banyaknya pelamar atau calon karyawan akan lebih baik banyak pula peluang memilih karyawan yang lebih baik.

5. Pengendalian biaya

Dengan sistem kompensansi yang baik akan mengurangi seringnya melakukan rekruitmen, sebagai akibat semakin seringnya karyawan yang keluar mencari pekerjaan yang lebih menguntungkan ditempat lain. Hal ini berarti menghematkan biaya untuk rekruitmen dan seleksi calon karyawan baru.

\subsubsection{Faktor-faktor yang mempengaruhi pemberian kompensansi}


Berbagai faktor yang mempengaruhi besarnya kompensansi yang di berikan perusahaan kepada karyawan. Dikemukakan oleh Hasibuan (2009:127-129) sebagai berikut:

1. Penawaran dan permintaaan

Jika pencari kerja (penawaran) lebih banyak dari pada lowongan pekerja (permintaan) maka kompensansi relatif kecil.sebaliknya jika pencari kerja lebih banyak sedikit dari pada lowongan pekerjaan maka kompensansi relatif semakin besar.

2. Kemampuan dan kesediaan perusahaan

Apabila kemampuan dan kesediaan perusahaan untuk membayar semakin baik, maka tingkat kompensansi akan semakin besar. Tetapi sebaiknya, jika kemampuan dan kesediaaan perusahaan untuk membayar kurang, maka tingkat kompensansi kecil.

3. Serikat buruh / organisasi karyawan

Apabila serikat buruhnya kuat dan berpemgaruh maka tingkat kompensansi semakin besar. Sebaliknya jika serikat buruh tidak kuat dan kurang berpengaruh maka tingkat kompensansi relatif kecil.

4. Produktivitas kerja karyawan

Jika produktivitas kerja karyawan baik dan banyak maka kompensansi akan semakin besar. Sebaliknya kalau produktivitas kerjanya buruk serta sedikit maka kompensansinya kecil.

5. Pemerintah dan undang - undang dan keppers 
Pemerintah dengan undang-undang dan keppers menetapkan besarnya batas upah/balas jasa minimum.peraturan pemerintah ini sangat penting supaya pengusaha tidak sewenang-wenang menetepkan besarnya balas jasa bagi karyawan. Pemerintah berkewajiban melindungi masyarakat dan tindakan sewenang-wenang.

6. Biaya hidup

Apabila biaya hidup didaerah ittu tinggi maka tingkat kompensansi/upah semakin besar.sebaliknya, jika tingkat biaya hidup didaerah itu rendah maka tingkat kompensansi/upah relatif kecil. Seperti tingkat upah di jakarta lebih besar dari upah pada di bandung.

7. Posisi jabatan karyawan

Karyawan yang menduduki jabatan lebih tinggi akan menerima gaji/kompensansi lebih besar. Sebaliknya karyawan yang menduduki jabatan yang lebih rendah akan memperoleh gaji/kompensansi yang kecil.hal ini wajar karena seseorang mendapat kewenangan dan tanggung jawab yang besar harus mendapat gaji/kompensansi yang lebih besar pula.

8. Pendidikan dan pengalaman kerja

Jika pendidikan lebih tinggi dan pengalaman kerja lebih lama maka gaji/balas jasanya akan semkin besar, karena kecakapan serta keterampilannya lebih baik. Sebaliknya, karyawan yang berpendidikan rendah dan pengalaman kerja yang kurang maka tingkat gaji kompensansinya kecil.

\subsubsection{Indikator - indikator kompensansi}

Menurut Mondy dan Noe (2008), indikator kompensasi karyawan yaitu 
1. Gaji

Gaji adalah imbalan finansial yang dibayarkan kepada karyawan secara teratur, sperti tahunan, caturwulan, bulanan atau mingguan.

2. Upah

Upah merupakan imbalan finansial langsung yang dibayarkan kepada para pekerja berdasarkan jam kerja, jumlah barang yang dihasilkan atau banyaknya pelayanan yang diberikan.

3. Insentif

Insentif merupakan imbalan langsung yang dibayarkan kepada karyawan karena kinerjanya melebihi standar yang ditentukan.

Menurut Simamora (2004), indikator untuk mengukur kompensasi karyawan diantaranya sebagai berikut:

1. Upah dan gaji

Upah adalah basis bayaran yang seringkali digunakan bagi para pekerja produksi dan pemeliharaan. Upah pada umumnya berhubungan dengan tarif gaji per jam dan gaji biasanya berlaku untuk tarif bayaran tahunan, bulanan atau mingguan.

2. Insentif

Pengertian Insentif adalah tambahan kompensasi di atas atau di luar gaji atau upah yang diberikan oleh perusahaan.

3. Tunjangan 
Pengertian Tunjangan adalah asuransi kesehatan dan jiwa, program pensiun, liburan yang ditanggung perusahaan, dan tunjangan lainnya yang berkaitan dengan hubungan kepegawaian.

\section{Fasilitas}

Pengertian Fasilitas adalah pada umumnya berhubungan dengan kenikmatan seperti mobil perusahaan, akses ke pesawat perusahaan, tempat parkir khusus dan kenikmatan (baca: perlakuan khusus) yang diperoleh karyawan.

Menurut Hasibuan (2012: p.86) mengemukakan, secara umum ada beberapa indikator kompensasi yaitu :

1. Gaji

2. Upah

3. insentif

4. Fasilitas kantor

5. Tunjangan

Sedangkan menurut Onsardi (2018) indikator kompensasi terdiri dari gaji, insentif dan tunjangan-tungan. Dari pendapat ahli yang dirujuk, maka peneliti menggunakan indikator dari, kompensansi menurut Hasibuan (2012: p.86),mendefinisikan bahwa, Kompensasi merupakan hal yang sensitif bila dikaitkan dengan kelayakan dalam memenuhi kebutuhan, apalagi semakin besarnya tingkat kebutuhan saat ini sehingga gaji yang diberikan masih dirasa kurang cukup. Pemberian kompensasi yang makin baik akan mendorong karyawan untuk bekerja dengan makin baik dan produktif “. 


\subsubsection{Displin kerja}

Disiplin adalah sikap seseorang atau kelompok yang berniat untuk mengikuti aturan aturan yang telah ditetapkan. Dalam kaitannya dengan pekerjaan, pengertian disiplin kerja adalah suatu sikap dan tingkah laku yang menunjukkan ketaatan karyawan terhadap peraturan organisasi. Disiplin merupakan tindakan manajemen untuk mendorong para anggota organisasi memenuhi tuntutan berbagai ketentuan tersebut (Siagian, 2012).

Menurut Rivai (2009) disiplin kerja adalah suatu alat yang digunakan para menajer untuk berkomunikasi dengan karyawan agar mereka bersedia untuk mengubah suatu perilaku serta sebagi suatu upaya untuk meningkatkan kesadaran dan kesediaan seorang mentaati semua peraturan perusahaan dan norma-norma sosial yang berlaku.

Menurut Alex Nitisemito (2000:200) kedisplinan adalah suatu sikap tingkah laku dan perbuatan yang sesuai dengan peraturan dari perusahaan baik tertulis maupun tidak tertulis. Heidjrachman dan Husnan (2002:15) menyatakan "Disiplin adalah setiap perseorangan dan juga kelompok yang menjamin adanya kepatuhan terhadap perintah dan berinisiatif untuk melakukan suatu tindakan yang diperlukan seandainya tidak ada perintah. Berikut indikatornya ialah: penggunaan waktu secara efektif, ketaatan terhadap peraturan yang telah ditetapkan, dan datang dan pulang tepat waktu”.

Heidjrachman dan Husnan (2002:15) menyatakan "Disiplin adalah setiap perseorangan dan juga kelompok yang menjamin adanya kepatuhan terhadap perintah dan berinisiatif untuk melakukan suatu tindakan yang diperlukan 
seandainya tidak ada perintah. Berikut indikatornya ialah: penggunaan waktu secara efektif, ketaatan terhadap peraturan yang telah ditetapkan, dan datang dan pulang tepat waktu"

Disiplin kerja merupakan faktor yang dapat mempengaruhi kinerja karyawan, menurut Mangkuprawira (2007) bahwa disiplin kerja sangat mempengaruhi kinerja karyawan, hal ini disebabkan karena disiplin merupakan bentuk-bentuk latihan bagi karyawan dalam melaksanakan aturan-aturan perusahaan. Semakin disiplin karyawan semakin tinggi produktivitas kerja karyawan dan kinerja perusahaan.

Pengertian displin kerja dari berbagai ahli diatas dapat disimpulkan bahwa displin kerjaadalah suatu sikap dan tingkah laku yang menunjukkan ketaatan karyawan terhadap peraturan organisasi suatu yang dinilai dari apa yang dilakukan oleh seorang karyawan Dalam kerjanya dengan kata lain, kinerja individu adalah bagaimana seorang karyawan melaksanakan pekerjaannya atau untuk kerjanya

\subsubsection{Faktor-Faktor Yang Mempengaruhi Kedisplinan}

Menurut Singodimenjo(2011:86) Faktor-Faktor Yang Mempengaruhi Kedisiplinan Banyaknya faktor yang dapat mempengaruhi tegak tidaknya suatu disiplin kerja dalam dalam suatu perusahaan faktor-faktor tersebut antara lain:

1. Besar kecilnya pemberian kompensasi.

2. Ada tidaknya pengawasan dalam perusahaan.

3. Ada tidaknya keteladanan pimpinan dalam perusahaan

4. Ada tidaknya aturan pasti yang dapat di jadikan pegangan. 
5. Keberatan pimpinan dalam mengambil tindakan

6. Tidak adanya perhatian kepada pada karyawan.

\subsubsection{Macam-Macam Displin Kerja}

Menurut Anwar P. Mangkunegara ( 2008 ; 129 )Macam-Macam Disiplin

Kerja Ada 2 bentuk, yaitu disiplin preventif dan disiplin korektif

1. Disiplin preventif

Disiplin preventif adalah suatu upaya untuk menggerakan pegawai mengikuti dan mematuhi pedoman kerja, aturan-aturan yang telah digariskan oleh perusahaan.Tujuan dasarnya adalah untuk menggerakan pegawai berdisiplin diri. Dengan cara preventif, pegawai dapat memelihara dirinya terhadap peraturan-peraturan perusahaan. Pemimpin perusahaan mempunyai tanggung jawab dalam membangun iklim organisasi dengan disiplin preventif.Begitu pula pegawai harus dan wajib mengetahui, memahami semua pedoman kerja serta peraturan-peraturan yang ada dalam organisasi.Disiplin preventif merupakan suatu sistem yang berhubungan dengan kebutuhan kerja untuk semua bagian sistem yang ada dalam organisasi. Jika sistem organisasi baik, maka diharapkan akan lebih mudah menegakkan disiplin kerja

\section{Disiplin Korektif}

Disiplin korektif adalah suatu upaya menggerakan pegawai dalam menyatukan suatu peraturan dan mengarahkan untuk tetap mematuhi peraturan sesuai dengan pedoman yang berlaku pada perusahaan.Pada disiplin korektif, pegawai yang melanggar disiplin perlu diberikan sanksi sesuai dengan peraturan yang 
berlaku.Tujuan pemberian sanksi adalah untuk memperbaiki pegawai melanggar, memelihara peraturan yang berlaku, dan memberikan pelajaran kepada pelanggar.

Disiplin korektif memerlukan perhatian khusus dan proses prosedur yang seharusnya. Hal ini sesuai dengan pendapat Keith Davis (2006) yang mengemukakan bahwa: Corrective dicipline requires attention to due process, which means that procedures show concern for the rights of the employee involved. Major requirements for due process include the following: 1) A presumption of innocence until reasonable proff of an employee's role in an affense is presented; 2) The right to be heard and in some cases to be represented by another 21 person;3) Dicipline that reasonable in relation to the offense involved. Keith davis( 2006 ) berpendapat bahwa disiplin korektif memerlukan perhatian proses yang seharusnya, yang berarti bahwa prosedur harus menunjukkan pegawai yang bersangkutan benar-benar terlibat. Keperluan proses yang seharusnya itu dimaksudkan adalah pertama, suatu prasangka yang tak bersalah sampai membuktikan pegawai berperan dalam pelanggaran. Kedua, hak untuk didengar dalam beberapa kasus terwakilkan oleh pegawai lain. Ketiga, disiplin itu dipertimbangkan dalam hubungannya dengan keterlibatan pelanggaran.

\subsubsection{Hal-hal Yang Menunjang Kedesiplinan}

Menurut Alex S. Nitisemito(2002:123) ada beberapa hal yang dapat menunjang keberhasilan dalam pendisiplinan karyawan yaitu:

1. Ancaman 
Dalam rangka menegakkan kedesiplinan kadang kala perlu adanya ancaman meskipun ancaman yang diberikan tidak bertujuan untuk menghukum, tetapi lebih bertujuan untuk mendidik supaya bertingkah laku sesuai dengan yang kita harapkan.

\section{Kesejahteraan}

Untuk menegakkan kedesiplinan maka tidak cukup dengan ancaman saja, tetapi perlu kesejahteraan yang cukup yaitu besarnya upah yang mereka terima, sehingga minimal mereka dapat hidup secara layak.

3. Ketegasan

Jangan sampai kita membiarkan suatu pelangggaran yang kita ketahui tanpatindakan atau membiarkan pelanggaran tersebut berlarut-larut tanpa tindakan yang tegas.

4. Partisipasi

Dengan memasukan unsur partisipasi maka para karyawan akan merasa bahwaperaturan tentang ancaman hukuman adalah hasil persetujun bersama.

5. Tujuan dan Kemampuan

Agar kedesiplinan dapat dilaksanakan dalam praktek, maka kedesiplinan hendaknya dapat menunjang tujuan perusahaan serta sesuai dengan kemampuan dari karyawan.

6. Keteladanan Pimpinan

Mempunyai pengaruh yang sangat besar dalam menegakkan kedesiplinansehingga keteladanan pimpinan harus diperhatikan. 


\subsubsection{Hambatan Disiplin Kerja}

Selain faktor-faktor yang berpengaruh terhadap pembentukan disiplin kerja, terdapat pula faktor-faktor yang menghambat terbentuknya disiplin kerja dalam diri seseorang, faktor penghambat tersebut berasal dari dalam diri pegawai itu sendiri maupun dari lingkungan sekitarnya.

Menurut Dolet Unaradjan( 2003:30:32) faktor-faktor yang penghambat disiplin sekitarnya.

1. Masyarakat yang menekankan ketaatan yang utuh dan loyalitas penuh kepada atasan atau pimpinan.

2. Masyarakat yang selalu terbuka dan bersikap permisif.

3. Keadaan fisik atau biologis yang tidak sehat.

4. Keadaan psikis atau mental yang tidak sehat.

5. Sikap perfeksionis.

6. Perasaan rendah diri atau inferior.

7. Perasaan takut dan kuatir.

8. Perasaan tidak mampu.

9. Kecemasan.

10. Suara hati dan rasa bersalah yang keliru.

11. Kelekatan-kelekatan yang tidak teratur.

Faktor-faktor penghambat disiplin kerja berasal dari lingkungan sebagai faktor eksternal. Yaitu: masyarakat yang menekankan ketaatan yang utuh dan loyalitas penuh kepada atasan atau pimpinan dan masyrakat yang terlalu terbuka dan bersifat permisif. Sedangkan faktor-faktor yang berasal dari dalam diri 
seseorang, seperti: keadaan fisik dan psikis yang tidak sehat, sikap perfeksionis, perasaan rendah diri, perasaan takut dan kuatir, perasaan tidak mampu, kecemasan suara hati dan rasa bersalah yang keliru, dan kelekatan-kelekatan yang tidak teratur.

\subsubsection{Iindikator - Indikator Kedisplinan Kerja}

Rivai (2006) menyatakan indikator yang dapat digunakan untuk mengkaji disiplin kerja pegawai adalah:

1. Ketepatan waktu hadir dalam bekerja

Hal ini menjadi indikator yang mendasar untuk mengukur kedisiplinan, dan biasanya karyawan yang memiliki disiplin kerja rendah terbiasa untuk terlambat dalam bekerja.

2. Ketaatan terhadap standart kerja

Hal ini dapat dilihat melalui besarnya tanggung jawab karyawan terhadap tugas yang diamanahkan kepadanya.

3. Kepatuhan terhadap peraturan

Karyawan yang taat pada peraturan jam kerja tidak akan melalaikan prosedur kerja dan akan selalu mengikuti pedoman kerja yang ditetapkan perusahaan.

4. Tingkat kewaspadaan

Karyawan memiliki kewaspadaan tinggi akan selalu berhati-hati, penuh perhitungan dan ketelitian dalam bekerja, serta selalu menggunakan sesuatu secara efektif dan efisien.

5. Bekerja etis

Beberapa karyawan mungkin melakukan tindakan yang tidak sopan 
ke pelanggan atau terlibat dalam tindakan yang tidak

Menurut Sutrisno (2009), terdapat empat indikator disiplin kerja, yaitu:

1. Taat terhadap aturan waktu.

Dilihat dari jam masuk kerja, jam pulang, dan jam istirahat yang tepat waktu sesuai dengan aturan yang berlaku di perusahaan.

2. Taat terhadap peraturan perusahaan. Peraturan dasar tentang cara berpakaian, dan bertingkah laku dalam pekerjaan.

3. Taat terhadap aturan perilaku dalam pekerjaan.

Ditunjukan dengan cara-cara melakukan pekerjaan - pekerjaan sesuai dengan jabatan tugas, dan tanggung jawab serta cara berhubungan dengan unit kerja lain.

4. Taat terhadap peraturan lainya di perusahaan.

Aturan tentang apa yang boleh dan apa yang tidak boleh dilakukan oleh para pegawai dalam perusahaan.

Menurut Soejono(2000), indikator dari displin kerja yaitu:

1. Ketepatan waktu.

Para pegawai datang ke kantor tepat waktu, tertib dan teratur, dengan begitu dapat dikatakan disiplin kerja baik

2. Menggunakan peralatan kantor dengan baik.

Sikap hati-hati dalam menggunakan peralatan kantor dapat mewujudkan bahwa seseorang memiliki disiplin kerja yang baik, sehingga peralatan kantor dapat terhindar dari kerusakan

3. Tanggung jawab yang tinggi. 
Pegawai yang senantiasa menyelesaikan tugas yang dibebankan kepadanya sesuai dengan prosedur dan bertanggung jawab atas hasil kerja, dapat pula dikatakan memiliki disiplin kerja yang baik.

4. Ketaatan terhadap aturan kantor.

Pegawai memakai seragam kantor, menggunakan kartu tanda pengenal/identitas, membuat ijin bila tidak masuk kantor, juga merupakan cerminan dari disiplin yang tinggi

Dari 3 ahli yang dirujuk, maka peneliti menggunakan indikator dari, Disiplin kerja Menurut " Rivai (2006).Pengertian disiplin kerja dari berbagai ahli diatas dapat disimpulkan bahwa disiplin kerja adalah sikap atau tindakan seorang karyawan yang mematuhi peraturan-peraturan yang telah ditetapkan oleh perusahaan

\subsubsection{Pengaruh Kompensansi Terhadap Kinerja Karyawan}

Kompensansi merupakan salah satu bentuk pendorong agar dapat meningkatkan kinerja karyawan, yaitu dengan memberi timbal balik atau hadiah kepada karyawan yang berprestasi baik, dimana pemberian kompensansi ini diharapkan untuk meningkatkan kinerja karyawan.

Menurut Hasibuan (2017:119) Kompensasi adalah semua pendapatan yang berbentuk uang, barang langsung atau tidak langsung yang diterima karyawan sebagai imbalan atas jasa yang diberikan kepada perusahaan. Pembentukan sistem kompensasi yang efektif merupakan bagian penting dari manajemen sumber daya manusia karena membantu menarik dan mempertahankan pekerjaan-pekerjaan 
yang berbakat.Selain itu sistem kompensasi perusahaan memiliki dampak terhadap kinerja strategis.

Kinerja karyawan merupakan suatu hal yang sangat penting dalam usaha organisasi utuk mencapai tujuannya. Salah satu cara terbaik untuk meningkatkan kapasitas kinerja karyawan adalah dengan menghubungkan kompensansi dengan perkembangan karyawan. Apabila program kompensansi dirasakan adil dan kompentitif oleh karyawan, maka perusahaan akan lebih mudah untuk menarik karyawan yang potensial, mempertahankannya dan memotivasi karyawan agar lebih meningkat kinerjanya, sehingga produktivitas meningkat dan perusahan mampu menghasilkan produk dengan harga kompentitif. Sehingga perusahaan bukan hanya unggul dalam persaingan, namun juga mampu mempertahankan kelangsungan hidupnya, bahkan mampu meningkatkan profitabilitas dan mengembangakan usahanya, sehingga kompensansi mempunyai pengaruh positif dan signifikan terhadap kinerja karyawan ( Catherine Nathania, 2016).

Kompensansi sangat berpengaruh positif dan signiifikan terhadap kinerja karyawan di sebuah perusahaan, jika kompensansi diberikan secara tepat maka kinerja karyawan bisa meningkat ( Yinawati , 2016). Kinerja yang baik dan tinggi dapat membantu perusahaan memperoleh keuntungan sebaliknya, bila kinerja turun dapat merugikan perusahaan.

\subsubsection{Pengaruh Displin Kerja Terhadap Kinerja Karyawan}

Menurut Hasibuan (2017:193),kedisiplinan adalah kesadaran dan kesediaan seseorang mentaati semua peraturan perusahaan dan norma-norma sosial yang berlaku. Disiplin kerja menjadi suatu hal yang diutamakan di dalam sebuah 
perusahaan, karena dengan adanya kedisiplinan kehidupan perusahaan menjadi aman, tertib, lancar dan tujuan perusahaan tercapai. Semakin baik disiplin kerja, maka kinerja karyawan akan semakin meningkat. Sebaliknya, semakin rendah disiplin kerja karyawan maka kinerja karyawanakan menurun.

Disiplin kerja seperti tujuan dan kemampuan, balas jasa, sanksi hukum, ketegasan serta hubungan kemanusiaan dan kompensasi seperti gaji, bonus dan tunjangan bagi karyawan berprestasi. Disiplin kerja merupakan suatu sikap menghormati, patuh dan taat pada peraturan-peraturan yang berlaku. Disiplin kerja sangat penting karena dengan karyawan yang mempunyai disiplin kerja maka akan menghasilkan kualitas kerja, kuantitas kerja dan waktu kerja yang baik sehingga dapat meningkatkan kinerja karyawan. Kompensasi merupakan sesuatu yang diterima karyawan sebagai pengganti kontribusi jasa mereka pada perusahaan (Baharuddin, Alhabsji, \& Utami, 2013).

Dalam penelitian Ali Wairooy( 2017), Hasli penelitian ini menunjukan bahwa displin kerja berpengaruh positif dan signifikan terhadap kinerja karyawan. Jika displin kerja tinggi maka tingkat kinerja karyawan akan mengningkat. 


\subsection{Hasil penelitian yang relevan}

Tabel 2.1

Hasil Penelitian Yang Relevan

\begin{tabular}{|c|c|c|c|c|}
\hline $\begin{array}{l}\mathrm{N} \\
\mathrm{O}\end{array}$ & Nama & Judul Penelitian & Metode & Hasil \\
\hline 1 & $\begin{array}{l}\text { Ananta } \\
\text { Dwikristiant } \\
\text { o Satedjo } \\
\text { dan Sesilya } \\
\text { Kempa } \\
(2015)\end{array}$ & $\begin{array}{l}\text { Pengaruh } \\
\text { Kompensansi } \\
\text { dan Displin } \\
\text { Kerja Terhadap } \\
\text { Kinerja } \\
\text { Karyawan PT. } \\
\text { ModernWidya } \\
\text { Tehnical } \\
\text { Cabang } \\
\text { Jayapura }\end{array}$ & Kuantitatif & $\begin{array}{l}\text { Variabel kompensansi }\left(\mathrm{X}_{1}\right) \\
\text { berpengaruh negatif dan } \\
\text { signifikan terhadap kinerja } \\
\text { karyawan }(\mathrm{Y}) \text {.displin kerja } \\
\left(\mathrm{X}_{2}\right) \text { tidak berpengaruh } \\
\text { terhadap kinerja karyawan } \\
(\mathrm{Y}) \text {. }\end{array}$ \\
\hline 2 & $\begin{array}{l}\text { Andi } \\
\text { Armansyah, } \\
\text { Idris Azis , } \\
\text { Niluh Putu } \\
\text { Evvy } \\
\text { Rossanty } \\
(2018)\end{array}$ & $\begin{array}{l}\text { Pengaruh } \\
\text { Kompensansi } \\
\text { dan Displin } \\
\text { Kerja Terhadap } \\
\text { Kinerja Pegawai } \\
\text { Kantor BPJS } \\
\text { Kesehatan } \\
\text { Cabang Palu }\end{array}$ & Kuantitatif & $\begin{array}{l}\text { Kompensansi (X1) } \\
\text { berpengaruh positif dan } \\
\text { signifikan terhadap kinerja } \\
\text { karyawan(Y) } \\
\text { Displin kerja (X2) } \\
\text { berpengaruh positif dan } \\
\text { signifikan terhadap kinerja } \\
\text { karyawan(Y) } \\
\text { Kompensansi(X1) dan } \\
\text { displin kerja(X2) secara } \\
\text { simultan berpengaruh positif } \\
\text { dan signifikan terhadap } \\
\text { kinerja karyawan }(Y)\end{array}$ \\
\hline 3 & $\begin{array}{l}\text { Ali Wairooy } \\
(2017)\end{array}$ & $\begin{array}{l}\text { Pengaruh } \\
\text { Disiplin Kerja } \\
\text { dan Kompensasi } \\
\text { Karyawan pada } \\
\text { PT. Pertamina } \\
\text { (Persero), Tbk. } \\
\text { Pemasaran } \\
\text { Region VII }\end{array}$ & Kuantitatif & $\begin{array}{l}\text { kompensansi }\left(\mathrm{X}_{1}\right) \\
\text { berpengaruh positif secara } \\
\text { signifikan terhadap kinerja } \\
\text { karyawan(Y),displin kerja } \\
\left(\mathrm{X}_{2}\right) \text { berpengaruh signifikan } \\
\text { terhadap kinerja } \\
\text { karyawan(Y). }\end{array}$ \\
\hline 4 & \begin{tabular}{|l} 
Any \\
Isvandiari \\
$(2017)$
\end{tabular} & $\begin{array}{l}\text { Pengaruh } \\
\text { Kompensasi dan } \\
\text { Disiplin Kerja } \\
\text { Terhadap } \\
\text { Kinerja } \\
\text { Karyawan } \\
\text { Bagian Produksi }\end{array}$ & Kuantitatif & $\begin{array}{l}\text { Hasil penelitian } \\
\text { menunjukkan bahwa } \\
\text { kompensansi }\left(\mathrm{X}_{1}\right) \\
\text { berpengaruh positif dan } \\
\text { signifikan terhadapkinerja } \\
\text { karyawan }(\mathrm{Y}) \text {. Displin kerja } \\
\left(\mathrm{X}_{2}\right) \text { berpengaruh negatif dan }\end{array}$ \\
\hline
\end{tabular}




\begin{tabular}{|c|c|c|c|c|}
\hline $\mathrm{N}$ & Nama & Judul Penelitian & Metode & Hasil \\
\hline & & $\begin{array}{l}\text { PG. Meritjan } \\
\text { Kediri }\end{array}$ & & $\begin{array}{l}\text { signifikan terhadap kinerja } \\
\text { karyawan }(Y) \text {. }\end{array}$ \\
\hline 5 & $\begin{array}{l}\text { PutuAgus } \\
\text { Candra } \\
\text { Mahardika, } \\
\text { Wayan } \\
\text { Bagia, Ni } \\
\text { Nyoman } \\
\text { Yulianthini } \\
\text { ( } 2016 \text { ) }\end{array}$ & $\begin{array}{l}\text { Pengaruh } \\
\text { Kompensansi } \\
\text { Dan Displin } \\
\text { Kerja Terhadap } \\
\text { Kinerja } \\
\text { Karyawan Pada } \\
\text { Hotel Puri } \\
\text { Bagus Lovina }\end{array}$ & Kuantitatif & $\begin{array}{l}\text { Hasil penelitian } \\
\text { menunjukkan bahwa: } \\
\text { kompensasi(X1) dan disiplin } \\
\text { kerja(X2) berpengaruh positif } \\
\text { dan signifikan terhadap } \\
\text { kinerja karyawan(Y) }\end{array}$ \\
\hline 6 & $\begin{array}{l}\text { dina } \\
\text { kurniati } \\
(2018)\end{array}$ & $\begin{array}{l}\text { Pengaruh } \\
\text { Kompensansi dan } \\
\text { Displin Kerja } \\
\text { Terhadap Kinerja } \\
\text { Karyawandi PT. } \\
\text { Marinal } \\
\text { Indoprima Desa } \\
\text { Kapedi Sumenep }\end{array}$ & Kuantitatif & $\begin{array}{l}\text { Hasil penelitian } \\
\text { menunjukkan bahwa secara } \\
\text { Parsial Kompensasi } \\
\text { berpengaruh positif dan } \\
\text { signifikan terhadap Kinerja } \\
\text { Karyawan, Disiplin Kerja } \\
\text { berpengaruh positif dan } \\
\text { signifikan terhadap Kinerja } \\
\text { Karyawan.Dan secara } \\
\text { Simultan Kompensasi dan } \\
\text { disiplin kerja berpengaruh } \\
\text { positif dan signifikan } \\
\text { terhadap Kinerja Karyawan. }\end{array}$ \\
\hline 7 & $\begin{array}{l}\text { Ilham } \\
\text { Thaief, } \\
\text { ArisBaharu } \\
\text { ddin, } \\
\text { Priyono\& } \\
\text { Mohamad } \\
\text { Syafi'i Idrus } \\
\text { (2015) }\end{array}$ & $\begin{array}{l}\text { Effect of } \\
\text { Training, } \\
\text { Compensation } \\
\text { and Work } \\
\text { Discipline against } \\
\text { Employee Job } \\
\text { Performance }\end{array}$ & Kuantitatif & $\begin{array}{l}\text { The training, compensation } \\
\text { and work discipline } \\
\text { simultaneously and partially } \\
\text { have } \\
\text { significant effects toward the } \\
\text { employee work performance } \\
\text { in PT. PLN (Persero) Malang } \\
\text { Service and Network } \\
\text { Area. }\end{array}$ \\
\hline
\end{tabular}




\begin{tabular}{|c|c|c|c|c|}
\hline $\begin{array}{l}\mathrm{N} \\
\mathrm{o}\end{array}$ & Nama & Judul Penelitian & Metode & Hasil \\
\hline 8 & $\begin{array}{l}\text { Priyono, } \\
\text { Suheriyatma } \\
\text { nto } \\
\text { ( 2016) }\end{array}$ & $\begin{array}{l}\text { Influence } \\
\text { Satisfaction, } \\
\text { Compensation } \\
\text { and Work } \\
\text { Discipline the } \\
\text { Employee } \\
\text { Performance at } \\
\text { PT. Lion Air in } \\
\text { Batam }\end{array}$ & Kuantitatif & $\begin{array}{l}\text { From the results of the } \\
\text { regression equation the } \\
\text { influence of variables (job } \\
\text { satisfaction, compensation } \\
\text { and working discipline) with } \\
\text { the performance of } \\
\text { employees at PT. Lion Air } \\
\text { Batam, there was a strong } \\
\text { and significant influence, } \\
\text { because the higher job } \\
\text { satisfaction, compensation } \\
\text { and working discipline, the } \\
\text { higher the employee's } \\
\text { performance because it has a } \\
\text { probability value of less than } \\
0.05\end{array}$ \\
\hline 9 & $\begin{array}{l}\text { Komang Edy } \\
\text { Sukarta } \\
\text { Wirya ( } 2019 \\
\text { ) }\end{array}$ & $\begin{array}{l}\text { The Effect of } \\
\text { Compensation } \\
\text { and Work } \\
\text { Environment } \\
\text { on Work } \\
\text { Discipline } \\
\text { and } \\
\text { Performance } \\
\text { of Mini Mart } \\
\text { Employees in } \\
\text { Denpasar City }\end{array}$ & kuantitatif & $\begin{array}{l}\text { The results showed that } \\
\text { compensation has a positive } \\
\text { and significant effect on } \\
\text { work discipline. Work } \\
\text { environment have positive } \\
\text { and significant effect to work } \\
\text { discipline.The work } \\
\text { environment has a positive } \\
\text { and significant impact on } \\
\text { performance. Work } \\
\text { discipline has a positive and } \\
\text { significant impact on } \\
\text { performance }\end{array}$ \\
\hline
\end{tabular}

\subsection{Kerangka teoritik}

Berdasarkan pada kajian pustaka dan hasil-hasil penelitian sebelumnya, maka kerangka konsep penelitian dapat dilihat pada Gambar di bawah ini : 


\section{Gambar 1.1}

Kerangka teoritik

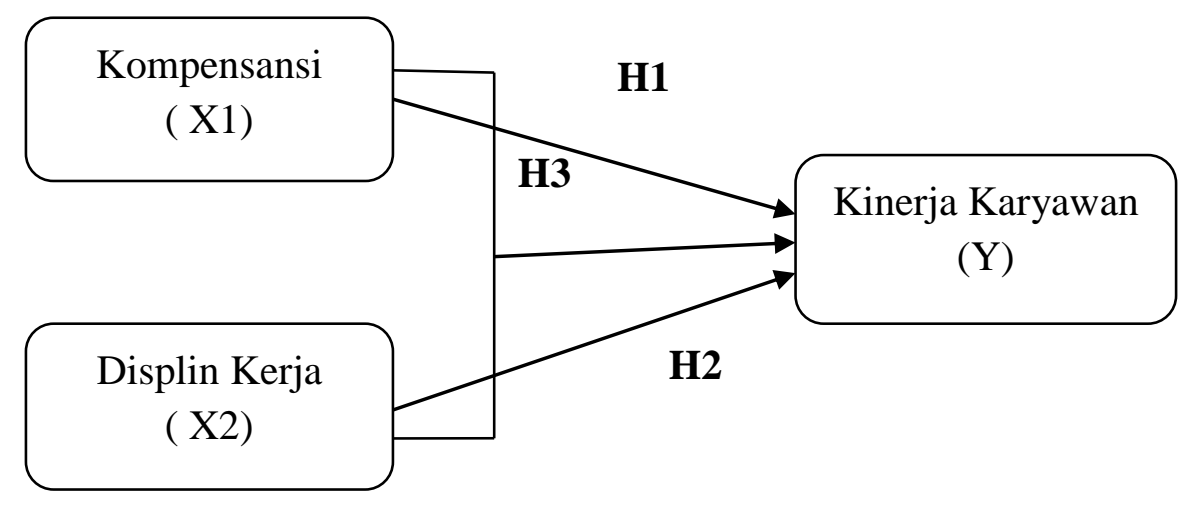

Keterangan :

1. H1 : Berpengaruh secara parsial varibale (X1) terhadap kinerja karyawan (Y)

2. H2 : Berpengaruh secara parsial variable (X2) terhadap kinerja karyawan (Y)

3. H3 : Berpengaruh secara simultan variable (X1) Dan (X2) terhadap kinerja karyawan (Y)

\subsection{Definisi operasional}

Definisi Operasional variabel ini mengacu pada beberapa definisi konseptual variabel penelitin yang telah dibahas dalam kajian pustaka, maka definisi operasional variabel penelitian dijelaskan pada bagian berikut. 
Tabel 2.2

Definisi Operasional

\begin{tabular}{|c|c|c|c|c|}
\hline Variabel & $\begin{array}{c}\text { Definisi } \\
\text { Operasional }\end{array}$ & Indikator & $\begin{array}{l}\text { Alat } \\
\text { Ukur }\end{array}$ & Skala \\
\hline \multicolumn{5}{|l|}{ Independen } \\
\hline $\begin{array}{l}\text { Kompensan } \\
\text { si }\left(X_{1}\right)\end{array}$ & $\begin{array}{l}\text { Kompensansi } \\
\text { merupakan bentuk } \\
\text { balas jasa untuk } \\
\text { karyawan yang di } \\
\text { berikan perusahaan }\end{array}$ & $\begin{array}{l}\text { 1. Gaji } \\
\text { 2. Upah } \\
\text { 3. Insentif } \\
\text { 4. Tunjangan } \\
\text { 5. Fasiliatas kantor } \\
\text { Menurut Hasibuan } \\
\text { (2012: p.86) }\end{array}$ & $\begin{array}{l}\text { Kuesione } \\
\mathrm{r}\end{array}$ & Ordinal \\
\hline $\begin{array}{l}\text { Displin } \\
\text { Kerja }\left(X_{2}\right)\end{array}$ & $\begin{array}{l}\text { Disiplin adalah } \\
\text { sikap seseorang } \\
\text { atau kelompok yang } \\
\text { berniat untuk } \\
\text { mengikuti aturan } \\
\text { aturan yang telah } \\
\text { ditetapkan. }\end{array}$ & $\begin{array}{l}\text { 1. Ketepatan waktu } \\
\text { hadir dalam } \\
\text { bekerja } \\
\text { 2. Ketaatan terhadap } \\
\text { standar kerja } \\
\text { 3. Kepatuhan } \\
\text { terhadap peraturan } \\
\text { 4. Tingkat } \\
\text { kewaspdaan } \\
\text { 5. Bekerja etis } \\
\text { Rivai (2006) }\end{array}$ & $\begin{array}{l}\text { Kuesione } \\
\mathrm{r}\end{array}$ & Ordinal \\
\hline \multicolumn{5}{|l|}{ Dependen } \\
\hline $\begin{array}{l}\text { Kinerja } \\
\text { Karyawan } \\
(\mathrm{Y})\end{array}$ & $\begin{array}{l}\text { Kinerja merupakan } \\
\text { suatu yang dinilai } \\
\text { dari apa yang } \\
\text { dilakukan oleh } \\
\text { seorang karyawan. }\end{array}$ & $\begin{array}{l}\text { 1.Kualitas } \\
\text { 2.Kuantitas } \\
\text { 3.Pelaksanakaan } \\
\text { tugas } \\
\text { 4.Tanggung jawab } \\
\text { Menurut } \\
\text { Mangkunegara } \\
(2009)\end{array}$ & $\begin{array}{l}\text { Kuesione } \\
\mathrm{r}\end{array}$ & Ordinal \\
\hline
\end{tabular}




\subsection{Hipotesis}

Dr. Sugiyono mengutarakan bahwa hipotesis merupakan jawaban sementara terhadap persamaan masalah penelitian.Jawaban masih berdasarkan teori yang relevan, tetapi belum didasarkan pada fakta-fakta empiris yang diperoleh dari pengumpulan data.Sutrisno Hadi menambahkan bahwa penolakan dan penerimaan hipotesis sangat tergantung pada hasil penyelidikan fakta-fakta yang dikumpulkan

Untuk kepentingan penelitian ini, sesuai dengan tujuannya diajukan hipotesis pengarah berikut:

1. Diduga Ada pengaruh yang positif dan signifikan antara kompensansi terhadap kinerja karyawan.

2. Diduga Ada pengaruh yang positif dan signifikan antara disiplin kerja terhadap kinerja karyawan.

3. Diduga Ada pengaruh yang positif dan signifikan antara kompensansi dan displin kerja terhadap kinerja karyawan. 


\section{BAB III \\ METODE PENELITIAN}

\subsection{Tempat dan Waktu Penelitian}

Penelitian ini dilakukan di PT.(SBS) Sinar Bengkulu Selatanyang beralamatkan di JL. Desa Nanjungan Kecamatan Pino Raya Kabupaten Bengkulu Selatan. Waktu yang digunakan dalam penelitian ini dari 15 Desember 2019 - 5 Januari 2020.

\subsection{Metode Penelitian}

Metode penelitian yang dipakai dalam penelitian ini menggunakan metode kuantitatif Dengan pendekatan tersebut diharapkan upaya pemahaman tentang Kompensansi dan Displin Kerja serta pengaruhnya terhadap kinerja karyawan dapat dilakukan secara lebih komprehensif. Data diambil dari karyawanPT.(SBS) Sinar BengkuluSelatan, melalui kuesioner.

\subsection{Populasi dan Sampel}

\subsubsection{Populasi}

populasi dalam suatu penelitian merupakan kumpulan individu atau obyek yang merupakan sifat-sifat umum. Arikunto (2010:173) Menjelaskan bahwa "populasi adalah keseluruhan subjek penelitian." Sedangkan menurut Sugiyono (2010:80) Populasi adalah "Wilayah generalisasi yang terdiri atas obyek atau subyekyang mempunyai kualitas dan karakteristik tertentu yang ditetapkan oleh peneliti untuk dipelajari dan kemudian ditarik kesimpulannya." maka dari penjelasan para ahli tersebut, penulis menetapkan populasi dalam penelitian ini adalah karyawan PT.(SBS) SinarBengkulu Selatan sejumlah 123 karyawan. 


\subsubsection{Sampel}

Sampel adalah bagian dari jumlah dan karakteristik yang dimiliki oleh populasi tersebut. Bila populasi besar, dan peneliti tidak mungkin mempelajari semua yang ada pada populasi, misalnya karena keterbatasan dana, tenaga dan waktu, maka peneliti dapat menggunakan sampel yang diambil dari populasi itu (Sugiyono, 2004). Dalam penelitian ini metode yang digunakan dalam pengambilan sampel menggunakan rumus Slovin (lihat Sevilla 1994) dalam Husein Umar (2008) yaitu sebagai berikut:

$$
n=\frac{N}{1+\mathrm{Ne}^{2}}
$$

Dimana:

$$
\begin{aligned}
\mathrm{n} \quad= & \text { Jumlah sampel } \\
\mathrm{N} \quad= & \text { Jumlah populasi } \\
\mathrm{E} \quad= & \text { Kelonggaran ketidaktelitian karena kesalahan pengambilan } \\
& \text { sampel yang dapat ditoleransi }(5 \%) .
\end{aligned}
$$

Penelitian ini menggunakan tingkat keandalan 90\% karena menggunakan tingkat kelonggaran ketidaktelitian sebesar 5\%. Menurut Sugiyono (2008 : 138) pembulatan ke atas dilakukan karena berdasarkan tabel ukuran sampel dan batas kesalahan untuk tingkat kelonggaran penelitian 5\%. Apabila dilakukan perhitungan menggunakan rumus, maka jumlah minimum yang di peroleh adalah:

$$
n=\frac{N}{1+\mathrm{Ne}^{2}}=\frac{123}{1+123 \cdot 0,05^{2}}=94,0726
$$

Maka sampel dibulatkan menjadi 95 orang. Sampel yang akan diambil dari populasi menggunakan convenience sampling, yaitu istilah umum yang mencakup 
variasi luasnya prosedur pemilihan responden. Convenience sampling merupakan pengumpulan informasi dari anggota populasi yang dengan senang hati bersedia memberikannya. Pengambilan 95 sampel yaitu dengan memberikan dan menjelaskan mengenai kuesioner pada karyawan.

\subsection{Teknik Pengumpulan Data}

Teknik pengumpulan data yang digunakan dalam penelitian ini adalah:

\section{Observasi}

Observasi merupakan metode penelitian dimana peneliti melakukan pengamatan secara langsung pada obyek penelitian.

\section{Kuesioner}

Kuesioner adalah cara mengajukan pertanyaan-pertanyaan yang sudah dipersiapkan secara tertulis dengan menyebarkan angket dan disertai dengan alternatif jawaban yang akan diberikan kepada responden diluar jam kerja atau pulang kerja dengan panduan kuesioner. Kuesioner dalam penelitian ini menggunakan pertanyaan terbuka dan tertutup.

Menurut Arikunto(2005), Kuesioner/angket adalah daftar pertanyaan yang diberikan kepada orang lain yang bersedia memberikan respon sesuai dengan permintaan pengguna.

Menurut Nazir(2007), kuesioner atau daftar pertanyaan adalah sebuat set pertanyaan yang secara logis berhubungan dengan masalah penelitian, dan tiap pertanyaan merupakan jawaban-jawaban yang mempunyai makna dalam menguji hipotesis. Daftar pertanyaan tersebut dibuat cukup terperinci dan lengkap. 
Instrument kuesioner harus diukur validitas dan reabilitas datanya sehingga penelitian tersebut menghasilkan data yang valid dan reliable. Instrumen yang valid berarti instrument tersebut dapat dipergunakan untuk mengukur apa yang seharusnya diukur, sedangkan instrument yang reliable adalah instrumen yang apabila digunakan beberapa kali untuk mengukur objek yang sama akan menghasilkan data yang sama pula. Instrumen yang digunakan untuk mengukur variabel penelitian ini dengan menggunakan skala Ordinal 5 poin (Prasetyo,2006). Jawaban responden berupa pilihan dari lima alternatif yang ada, yaitu :

Tabel 3.1

Interval Skor Skala Ordinal

\begin{tabular}{|l|l|c|c|}
\hline No & \multicolumn{1}{|c|}{ Keterangan } & Kode & Skor \\
\hline 1. & Sangat Setuju & SS & 5 \\
\hline 2. & Setuju & S & 4 \\
\hline 3. & Ragu-Ragu & RR & 3 \\
\hline 4. & Tidak Setuju & TS & 2 \\
\hline 5. & Sangat Tidak Setuju & STS & 1 \\
\hline
\end{tabular}


Tabel 3.2

Kisi-Kisi Kuesioner

\begin{tabular}{|c|c|c|c|c|}
\hline No & Variable & Indikator & No. Item & Jumlah \\
\hline 1 & $\begin{array}{l}\text { Kompesansi } \\
\text { (X1) }\end{array}$ & $\begin{array}{l}\text { 1. Gaji } \\
\text { 2. Upah } \\
\text { 3. Insentif } \\
\text { 4. Tunjangan } \\
\text { 5. Fasilitas kantor }\end{array}$ & $\begin{array}{c}1-2 \\
3-4 \\
5-6 \\
7-8 \\
9-10\end{array}$ & $\begin{array}{l}2 \\
2 \\
2 \\
2 \\
2\end{array}$ \\
\hline Total & & 5 & 5 & 10 \\
\hline 2 & $\begin{array}{l}\text { Displin Kerja } \\
\text { (X2) }\end{array}$ & $\begin{array}{l}\text { 1. Ketepatan waktu dalam } \\
\text { bekerja } \\
\text { 2. Ketaatan terhadap } \\
\text { standar kerja } \\
\text { 3. Kepatuhan terhadap } \\
\text { peraturan } \\
\text { 4. Tingkat kewaspadaan } \\
\text { 5. Bekerja etis }\end{array}$ & $\begin{array}{c}1-2 \\
3 \\
4-5 \\
6-7 \\
8-9\end{array}$ & $\begin{array}{l}2 \\
1 \\
2 \\
2 \\
2\end{array}$ \\
\hline Total & & 5 & 5 & 9 \\
\hline 3 & $\begin{array}{l}\text { Kinerja } \\
\text { Karyawan(Y) }\end{array}$ & $\begin{array}{l}\text { 1. Kualitas } \\
\text { 2. Kuantitas } \\
\text { 3. Pelaksanakaan tugas } \\
\text { 4. Tanggung jawab }\end{array}$ & $\begin{array}{l}1-2 \\
3-4 \\
5-6 \\
7-8\end{array}$ & $\begin{array}{l}2 \\
2 \\
2 \\
2\end{array}$ \\
\hline Total & & 4 & 5 & 8 \\
\hline
\end{tabular}

\subsection{Uji Instrumen}

Pengujian instrumen penelitian ini yaitu menguji validitas dan realibelitas instrumen.Penggunaan metode pengumpulan data dengan kuisioner, maka kesungguhan responden mengisi merupakan hal yang penting. Adapun uji instrument yang dimaksud adalah menguji valid dan reliabelitas yang dilakukan pada sampel uji, ditentukan dengan sampel khusus sejumlah 20 orang responden 
diluar sampel penelitian yaitu karyawan PT.(SBS) Sinar Bengkulu Selatan, instrument yang valid dan reliabel merupakan syarat mutlak untuk mendapatkan hasil penelitian yang diharapkan.Data yang telah terkumpul diuji dengan menggunakan bantuan program SPSS.

\subsubsection{Uji Validitas}

Uji validitas adalah untuk mengetahui sah tidaknya instrumen kuesioner yang digunakan dalam pengumpulan data. Uji validitas ini dilakukan untuk mengetahui apakah item-item yang tersaji dalam kuesioner benar-benar mampu mengungkapkan dengan pasti apa yang akan diteliti (Imam Ghozali, 2012).

Menurut sugiyono (2013) menyatakan item yang mempunyai korelasi positif dengan kriterium (skor total) serta korelasi yang tinggi pula menunjukan bahwa item tersebut mempunyai validitas yang tinggi pula. Cara untuk mencari nilai validitas dari sebuah item adalah dengan mengkorelasikan skor item tersebut dengan total skor item-item dari variabel tersebut, apabila nilai korelasi diatas 0,30 maka dikatakan item tersebut memberikan tingkat kevalidan yang cukup, sebaliknya apabila nilai korelasi dibawah 0,30 maka dikatakan item tersebut kurang valid. Metode korelasi yang digunakan adalah Pearson Product Moment sebagai berikut :

$$
\mathrm{r}=\frac{n \sum X i Y i-\left(\sum X i\right)\left(\sum Y i\right)}{\sqrt{\left\{n \sum X i^{`} 2-\left(\sum X i\right)^{2} 2\right\}\left\{n \sum Y i{ }^{\imath}-\left(\sum Y i\right)^{`} 2\right\}}}
$$

Setelah angka korelasi diketahui, kemudian dihitung nilai t dari $\mathrm{r}$ dengan rumus:

$$
\mathrm{t}=\frac{r \sqrt{\mathrm{n}}-2}{\sqrt{1}-\mathrm{r}^{\wedge}}
$$

Setelah itu, dibandingkan dengan nilai kritisnya. Bila thitung $>t_{\text {tabel }}$, berarti data tersebut signifikan dan layak digunakan dalam pengujian hipotesis penelitian. 
Sebaliknya bila thitung $\leq$ ttabel , berarti data tersebut tidak signifikan dan tidak akan diikutsertakan dalam pengujian hipotesis penelitian. Pernyataan-pernyataan yang valid selanjutnya dilakukan uji reliabilitasnya.

Uji validitas dalam penelitian ini menggunakan program SPSS. Validititas suatu butir pertanyaan dapat dilihat pada hasil output SPSS pada tabel dengan judul Item - Total Statistic. Menilai kevalidan masing-masing butir pertanyaan dapat dilihat dari nilai Corrected item-Total Correlation masing-masing butir pertanyaan. Suatu butir pertanyaan dikatakan valid jika nilai r-hitung yang merupakan nilai dari Corrected item-Total Correlation > 0,30 (Priyatno, 2012).

Hasil uji validitas dari data yang didapat di PT.(SBS) Sinar Bengkulu Selatan jalan Desa Nanjungan Kecamatan Pino Raya Kabupaten Bengkulu Selatan

Table 3.3

Ringkasan Hasil Uji Validitas Variabel Kompensansi, Displin Kerja, Dan Kinerja Karyawan

\begin{tabular}{|l|l|l|l|}
\hline Variabel & Pernyataan & $\begin{array}{l}\text { Total Pearson } \\
\text { Correlation }\end{array}$ & Keterangan \\
\hline Kompensasi $\left(\mathrm{X}_{1)}\right.$ & 1 & 0.693 & Valid \\
& 2 & 0.793 & Valid \\
& 3 & 0.755 & Valid \\
4 & 0.474 & Valid \\
& 5 & 0.518 & Valid \\
& 6 & 0.461 & Valid \\
& 8 & 0.509 & Valid \\
& 9 & 0.350 & Valid \\
& 10 & 0.576 & Valid \\
& 9 & 0.520 & Valid \\
\hline
\end{tabular}




\begin{tabular}{|l|l|l|l|}
\hline DisiplinKerja & 1 & 0.795 & Valid \\
$\left(\mathrm{X}_{2}\right)$ & 2 & 0.690 & Valid \\
& 3 & 0.795 & Valid \\
& 4 & 0.458 & Valid \\
& 5 & 0.781 & Valid \\
& 6 & 0.865 & Valid \\
& 7 & 0.841 & Valid \\
& 8 & 0.455 & Valid \\
& 9 & 0.613 & Valid \\
\hline KinerjaKaryawan & 1 & 0.710 & Valid \\
& 2 & 0.532 & Valid \\
& 3 & 0.587 & Valid \\
& 4 & 0.480 & Valid \\
& 5 & 0.675 & Valid \\
6 & 0.569 & Valid \\
& 7 & 0.480 & Valid \\
8 & 0.665 & Valid \\
\hline
\end{tabular}

Sumber : Data diolah, 2019

Dari table 3.3 diatas bahwa semua indikator yang digunakan untuk mengukur variabel-variabel yang digunakan dalam penelitian ini mempunyai koefesien korelasi yang lebih besar dari 0.30 sehingga semua indikator tersebut valid.

\subsubsection{Uji Reliabilitas}

Menurut Sugiyono (2010: 3) reliabilitas adalah derajat konsistensi atau keajegan data dalam interval waktu tertentu. Uji reliabilitas digunakan untuk 
mengetahui sejauh mana hasil pengukurantetap konsisten bila dilakukan pengukuran beberapa kali dengan gejala yang sama. Tinggi rendahnya reliabilitas ditunjukkan olah suatu angka koefisienreliabilitas. Untuk mengukur tinggi rendahnya reliabilitas salah satunya dapat menggunakan teknik pengkuran koefisien alpha dari Cronbanch. Semakin mendekati koefisien 1 alphadari variabel semakin tinggi konsistensi jawaban skor dari tiap indikator. Reliabilitas yang kurang dari 0,60 dipertimbangkan kurang baik, dan sebaliknya jika di atas 0,60 sangat baik (Sekaran, 2006: 182). Uji reliabilitas dilakukan terhadap skor jawaban atas kuesioner yang diberikan terhadap responden dengan menggunakan program SPSS.

Hasil uji reliabilitas dari data yang didapat di PT.(SBS) Sinar Bengkulu Selatan di Jalan Desa Nanjungan Kecamatan Pino Raya Kabupaten Bengkulu Selatan

Table 3.4

RingkasanHasilNilaiCrobachAlpa Dari TiapVariabel

\begin{tabular}{|l|l|l|l|l|}
\hline Variabel & $\begin{array}{l}\text { NilaiCronbach } \\
\text { Alpa }\end{array}$ & $\begin{array}{l}\text { CutOf } \\
\text { Value }\end{array}$ & $\begin{array}{l}\text { JumlahPernyata } \\
\text { an }\end{array}$ & Keterangan \\
\hline Kompensansi & 0.760 & 0.60 & 10 & Reliabel \\
\hline DisiplinKerja & 0.854 & 0.60 & 9 & Reliabel \\
\hline KinerjaKaryawan & 0.717 & 0.60 & 8 & Reliabel \\
\hline
\end{tabular}

Sumber : Data diolah, 2019 
Dari table 3.4 di atas terlihat bahwa semua variabel memiliki nilai cronbach alpa lebih besar dari 0.60 maka dapat disimpulkan bahwa semua variabel penelitian ini reliable.

\subsection{Teknik analisis deskriptif}

Bagian analisis ini akan membahas mengenai bentuk tanggapan responden terhadap kuesioner yang disebarkan kepada responden. Dari sebaran jawaban responden selanjutnya akan diperoleh satu kecenderungan jawaban responden terhadap jawaban masing-masing variabel akan didasarkan pada nilai rata-rata skor yang selanjutnya akan dikonfirmasikan pada tabel interval penelitian, adapun perhitungan rata-rata dari responden menggunakan rumus sebagai berikut :

$$
\mathrm{X}=\frac{\sum x}{N}
$$

Keterangan

$\mathrm{X}=$ angka rata-rata

$\mathrm{N}=$ jumlah skor

$\sum \mathrm{x}=$ nilai responden

Hasil rata-rata jawaban responden tersebut dikonfirmasikan pada interval penelitian menetapkan rentang interval penelitian tersebut. Dihitung berdasarkan rumus sebagai berikut :

$$
\mathrm{I}=\frac{R}{K}
$$

Keterangan :

$\mathrm{I}=$ interval

$\mathrm{R}=$ range (nilai tertinggi-nilai terendah) 
$\mathrm{K}=$ jumlah kategori

$=\frac{5-1}{5}=0.8$

Setelah besarnya interval diketahui, kemudian dibuat rentang skala hingga dapat ditentukan kriteria penelitian persepsi responden terhadap variabel-variabel penelitian sebagai berikut :

Interval penelitian variabel penelitian

Tabel 3.5

Tanggapan Responden Terhadap Variabel

\begin{tabular}{|l|l|}
\hline Interval koefisien & Tingkat hubungan \\
\hline $4,20-5,00$ & Sangat setuju \\
$3,40-4,19$ & Setuju \\
$2,60-3,39$ & Ragu-Ragu \\
$1,80-2,59$ & Tidak setuju \\
$1,00-1,79$ & Sangat tidak setuju \\
\hline
\end{tabular}

\subsection{Uji Asumsi Klasik}

Mengingat data penelitian yang digunakan adalah sekunder, maka untuk memenuhi syarat yang ditentukan sebelum uji hipotesis melalui uji $\mathrm{t}$ dan uji $\mathrm{F}$ maka perlu dilakukan pengujian atas beberapa asumsi klasik yang digunakan yaitu normalitas, mulltikolinieritas, autokolerasi, dan heteroskedastisitas yang secara rinci dapat dijelaskan sebagai berikut: 


\subsubsection{Uji Asumsi Klasik Normalitas (Sunyoto, 2009)}

Bertujuan untuk mengukur apakah di dalam model regresi variabel independen dan variabel dependen keduanya mempunyai distribusi normal atau mendekati normal (Ghozali, 2011:160). Dasar pengambilan keputusan untuk uji normalitas adalah :

1. Jika data menyebar disekitar garis-garis diagonal dan mengikuti arah garis diagonal atau graik histogramnya menunjukkan distribusi normal, maka model regresi memenuhi asumsinormalitas.

2. Jika data menyebar jauh dari diagonal atau tidak mengikuti arah garis diagonal atau grafik histogram tidak menunjukkan distribusi normal, maka model regresi tidak memnuhi asumsinorma

\subsubsection{Uji Heterokedastisitas}

Bertujuan untuk menguji apakah model regresi ketidaksamaan varians dari residuals satu pengamatan ke pengamatan lainnya (Ghozali, 2011:139).

\subsubsection{Uji Multikolinieritas}

Pengujian ini bertujuan apakah model regresi ditemukan adanya korelasi antar variabel independen.Model regresi yang baik seharusnya tidak terjadi korelasi antar variabel independen (Ghozali, 2011:105).Uji multikolonieritas dilakukan dengan milihat besarnya variance invelation faktor (VIF) dan tolerance. Jika nilai VIF $>10$ dan tolerance $<0,1$ hal ini berarti terjadi korelasi antar variabel independen dan sebaliknya jika nilai VIF $<10$ dan nilai tolerance $>$ 0,1 hal ini berarti tidak terjadi korelasi antar variabel (Ghozali, 2009:96) 
Mengacu pada ketentuan tersebut, maka jawaban dari setiap responden dapat dihitung skornya yang kemudian skor tersebut ditabulasikan untuk menghitung validitas dan reliabilitasnya.

\subsection{Analisis Regresi Linier Berganda}

Teknik analisis yang digunakan dalam penelitian ini adalah Analisis regresi linear berganda digunakan untuk mengetahui pengaruh antara variabel bebas dengan variabel terikat, yaitu Kompensansi (X1) danDisplin Kerja (X2)Terhadap Kinerja karyawan (Y) pada PT.(SBS) SinarBengkulu Selatan. Adapun rumus regresi linear berganda adalah sebagai berikut (sugiyono, 2008):

$$
\mathrm{Y}=\mathrm{a}+\mathrm{b} 1 \mathrm{X} 1+\mathrm{b} 2 \mathrm{X} 2+=\mathrm{e}
$$

Keterangan :

$\mathrm{Y}=$ Kinerja karyawan

$\mathrm{a}=$ Koefisien regresi (konstanta)

b1 = Koefisien regresi Kompensansi

b2 = Koefisien regresi Displin Kerja

$\mathrm{X} 1=$ Kompensansis

X2 = Displin Kerja

$\mathrm{e}=$ Standar error / variabel penggangg

\subsection{Analisisis Koefisien Determinasi $\left(\mathbf{R}^{2}\right)$}

Koefisien determinasi merupakan suatu alat untuk mengukur besarnya pengaruh variabel independen terhadap variabel dependen.Nilai $\mathrm{R}^{2}$ yang kecil 
berarti kemampuan variabel-variabel independen dalam menjelaskan variasi variabel dependen sangat terbatas.Nilai yang hampir mendekati 1 (satu) berarti variabel-variabel independen memberikan hampir semua informasi yang dibutuhkan untuk memprediksi variasi dependen, artinya semakin besar pengaruh variabel independen terhadap variabel dependen. (Sugiyono, 2013: 260) Besarnya koefisien determinasi dapat dihitung dengan menggunakan rumus sebagai berikut:

$$
R^{2}=b 1 \times 100 \%
$$

Dimana :

$$
\begin{aligned}
& \mathrm{Kd}=\text { Koefisien determinasi } \\
& R^{2}=\text { Koefisien korelasi }
\end{aligned}
$$

Kriteria untuk analisis koefisien determinasi adalah:

1. Jika Kd mendeteksi nol (0), maka pengaruh variabel independent terhadap variabel dependent lemah.

2. Jika Kd mendeteksi satu (1), maka pengaruh variabel independent terhadap variabel dependent kuat.

\subsection{Uji Hipotesis}

\subsubsection{Uji Parsial (t-test)}

Uji signifikansi parameter individual (uji statistik t) bertujuan untuk mengukur pengaruh satu variabel independen secara individul dalam menerangkan variasi variabeldepend.

Taraf signifikansi yang penulis gunakan dalam uji t ini adalah pada tingkat kepercayaan $95 \%$ atau $(\alpha=0,050)$. Apabila nilai signifikansi $<0,050$ maka 
dinyatakan bahwa variabel independen berpengaruh terhadap variabel dependen, sebaliknya apabila nilai signifikansi > 0,050 maka dinyatakan bahwa variabel independen tidak berpengaruh terhadap variabel dependen.

$$
\mathrm{t}=\quad \begin{aligned}
& b i \\
& S b i
\end{aligned}
$$

(Sugiyono, 2013:270)

Keterangan:

$\mathrm{t}=$ Nilai $\mathrm{t}$ Hitung

bi= koefisien Regresi

Dalam pengujian ini dilakukan dengan bantuan program SPSS dengan kriteria pengujian sebagai berikut :

1. Jika thitung > ttabel maka Ha diterima dan Ho ditolak, berarti secara parsial ada pengaruh yang signifikan variabel X1 dan X2 terhadap variabel Y.

2. Jika thitung < ttabel maka Ha ditolak dan Ho diterima, berarti secara parsial tidak ada pengaruh yang signifikan variabel X1 dan X2terhadap variabel Y.

\subsubsection{Uji Simultan (F-test)}

Adapun untuk menguji hipotesis secara keseluruhan (simultan) digunakan

Uji $F: F h i t=\frac{R 2(n-k-l)}{k(l-R 2)}$

Keterangan :

Fh $\quad=$ Pengujian signifikansi koefisien regresi berganda

$\mathrm{R}=$ Koefisien regresi berganda

$\mathrm{K}$ = Jumlah variabel independen

$\mathrm{n} \quad=$ Jumlah anggota sampel 
Uji simultan (uji F) ini digunakan untuk melihat apakah variabel independent yaitu Kompensansi (X1) danDisplin Kerja (X2) mempunyai pengaruh yang positif dan signifikan terhadap variabel dependen yaitu Kinerja Karyawan (Y). Kriteria pengambilan keputusan dalam uji F dengan menggunakan SPSS adalah :

1. Jika nilai signifkansi $>0,050$, maka Ho diterima dan Ha ditolak, atau variabel bebas dari model regresi linear tidak mampu menjelaskan variabel terikat.

2. Jika nilai signifikasi $<0,050$, maka Ho ditolak dan Ha diterima, atau variabel bebas dari model regresi linear mampu menjelaskan variabel terikat.

\section{BAB IV}

\section{HASIL DAN PEMBAHASAN}

\subsection{Hasil Penelitian}

\subsubsection{Sejarang Singkat PT.(SBS) Sinar Bengkulu Selatan}

PT.(SBS) Sinar Bengkulu Selatan adalah sala satu unit usaha yang kantor PT. TPP ini perusahaan Group Trinity Interlink dengan kantor pusat di Medan, Sumatera Utara. kini pindah menjadi (SBS grub) berkantor di Medan-Sumatra Utara, Berdirinya PT.(SBS) Sinar Bengkulu Selatan bersetatus sebagai PT (Persero Terbatas). Kemudian PT.(SBS) Sinar Bengkulu Selatan mendapatkan izin perusahaan dari badan koordinasi penanaman modal NO. 79/V/PMA/2015 pada tanggal 29 Maret 2015, selanjutnya NO. 1171/III/PMA/2014 pada tanggal 20 januari 2014.

PT.(SBS) Sinar Bengkulu Selatan dimulai pembangunan sejak tahun 2011 dan star operasional/commissioning mulai dari bulan maret 2013 dengan line 
sampai dengan saat ini. Adapun sumber bahan baku FFB terdiri dari FFB petani, karena kebun yang di miliki prusahaan belum mencapai masa panen, sedangkan utuk produksi yang di hasilkan dari CPO, Kernel, serta cangkang dibeli oleh supplier dari Medan, Palembang, Jambi, Lampung, Bengkulu, dan Jakarta.

PT.(SBS) Sinar Bengku Selatan sebuah perusahaan yang berdiri sejak tahun 2014 yang di dirikan oleh Bapak Ajie Sumargo bergerak pada bidang pengelolaan minyak kelapa sawit dan di resmikan oleh wakil Gubernur Bengkulu Sultan B.Najamudin dan bupati Bengkulu Selatan H. Reskan E.Awaludin di desa Nanjungan, 20 Januari 2014.

\subsubsection{Visi Dan Misi PT. Sinar Bengkulu Selatan}

Adapun visi misi PT.(SBS) Sinar Bengkulu Seltan adalah sebagai berikut :

1. Visi

Menjadi perusahaan Agribisnis yang bermutuh, tangguh dan berkelanjutan dalam hal produksi, biaya dan lingkungan.

2. Misi

1. Memberdayakan sumberdaya yang efektif, efisien dan dinamis dlam menghasilakan produk yang bermutuh dan berkelanjutan.

2. Mensejahtrakan karyawan dan meningkatkan produk untuk mendapatkan keuntungan yang optimal bagi perusahaan PT.(SBS) Sinar Bengkulu Selatan. 


\subsubsection{Deskripsi jabatan PT.(SBS) Sinar Bengkulu Selatan}

\section{Mill Manager PT.(SBS) Sinar Bengkulu Selatan}

Bertugas melaksanakan fungsi managerial untuk mengawasi tenaga kerja , mesin/instansi, sarana dan prasarana serta pengaturan persyaratan untuk mengelolah tandan buah segar (TBS), yang diterima perusahaan menjadikan minyak mentah kelapa sawit dengan mutu yang baik dan sesuai, menerima tugas dari deriksi sebagai penanggung jawab mengelolah dan mengopersikan pabrik kelapa sawit sesuai dengan ketentuan perusahaan.

2. Kepala tata usaha PT.(SBS) Sinar Bengkulu Selatan

Bertugas mengelolah semua kegiatan administrasi dan keuangan dalam lingkungan pabrikuntuk mendapatkan data yang benar dan akurat sehingga menghasilkan lapoaran dan informasi yang tepat waktu, relevan dan konsisten sebagai alat pengedaliaan, pengamanan aset dan sumber daya serta pengambilan keputusan.

3. Asssiten mill manager PT.(SBS) Sinar Bengkulu Selatan

1) Bertanggung jawab kepada mill manager sebagai atasan langsung

2) Bertanggung jawab dalam merencanakan, mengarahakan, memonitor dan mengevaluasi sistem kerja di pabrik pengelohan kelapa sawit

3) Mengarahkan fungsi dan kinerja unit pabrik pengelohan kelapa sawit agara berjalan optimal dan meningkatkan kinerja SDM.

4) Mampu menjalankan kebijakan K3 (Kesehatan dan Keselamatan Kerja)

5) Menjalankan tugas-tugas terkait lainya dalam upaya pencapaaian target perusahaan 
6) Menyusun rencana kerja dan budget dari target jangka pendek yang di tetapkan oleh mill manager yang mencakup juga rencana kebutuhan , bahan pendukung, alat bantu serta sarana dan prasarana yang dibutuhkan.

7) Membuat laporan harian, mingguan,bulanan dan tahunan mengenai perkembangan (progress) pekerja ataupun permasalahan dilapangan kepada mill manager.

4. Kepala Gudang PT.(SBS) Sinar Bengkulu Selatan

1) Membuat perencanaan pengadaan barang dan distribusinya

2) Mengawasi dan mengontrol operasional gudang

3) Menjadi pimpinan bagi semua staff gudang

4) Mengawasi dan mengontrol semua barang yang masuk dan keluar sesuai SOP

5) Memastikan aktivitas keluar masuk barang berjalan lancar

6) Melaporkan semua transaksi keluar masuk barang kepada mill manager PT.(SBS) Sinar Bengkulu Selatan.

5. Kerani gudang PT.(SBS) Sinar Bengkulu Selatan

1) Memeriksa semua barang yang akan disimpan digudang kemudiaan menerima dan menyimpanya dengan baik

2) Melakukan dengan pengeluaran barang sesuai permintaan kepala seksi yang lain

3) Membuat bukti penerimaan dan pengeluaran barang dari gudang

4) Membantu internal audit atau pihak lain yang akan melakukan stock opname 
5) Mencegah sembarang orang keluar masuk gudang

6) Melakukan tindakan yang dianggap perlu untuk mengamankan barangbarang yang berada di bawah pengawasan.

6. Kerani timbangan PT.(SBS) Sinar Bengkulu Selatan

1) Melakukan penimbangan masuk dan keluar atas kendaraan angkutan MKS/IKS/TBS dan kendaraan angkutan lainya.

2) Memastikan kendaraan dalam keadaan siap di untuk ditimbang

3) Membuat rekapitulasi data timbangan menurut pabrik dengan data timbangan menurut pihak ketiga

7. Kasir PT.(SBS) Sinar Bengkulu Selatan

1) Menjalankan proses penjualan dan pembayaran

2) Melakukan pencatatan atas semua transaksi

3) Membantu pelanggan dalam memberikan informasi mengenai suatu produk

4) Melakukan proses transaksi pelayanan jual beli serta melakukan pembungkusan

5) Melakukan pengecekan atas semua jumlah barang pada saat penerimaan barang.

8. Adminitrasi PT.(SBS) Sinar Bengkulu Selatan

1) Bertanggung jawab terhadap adminitrasi penjualaan/pembeliaan TBS,CPO, kernel dan produk lainya yang berhubungan dengan perkebunan kelapa sawit.

2) Bertanggung jawab terhadap adminitrasi kesekretariatan

3) Mengerti dan memahami proses adminitrasi dan penjualaan secara baik 
4) Menjalin kordinasi dan menjalin kerjasama dengan seluruh department didalam melaksanakan pekerjaan

5) Komunikatif,jujur dan mempunyai daya analisis yang kuat

9. Mandor compout PT.(SBS) Sinar Bengkulu Selatan

1) Memimpin apel pagi pada kelompok kerja sekaligus memastikan anggotanya berangkat kerja pagi

2) Menentukan atau membagi acak panen pada pagi hari, sambil membagiak ‘ notes potong buah, kue ' pada masing-masing pemanen

3) Mengecek kelengkapan dan kesepiaan peralatan panen

10. Danruh atau agen secuirty PT.(SBS) Sinar Bengkulu Selatan

1) Mengamankan suatu asset, instansi, proyek bangunan, propertiatau tempat dan melakukan pemantau peralatan, pengawasan, pemeriksaan dan jalur akses, untuk memastikan keamanan dan mencegah kerugiaan atau kerusakaan yang disengaja.

2) Mencegah dan deteksi dini penyusup, kegiataan atau orang yang masuk secara tak sah, vandalisme atau penerobos/peloncat pagar di wilayah kuasa tempat perusahaan

3) Melakukan upaya kepatuhan, penegakan tata tertib dan menerapkan kebijakan perusahaan, peraturan kerja dan praktik-pratik dalam rangka pencegahan tindak kejahatan

4) Mealpor dan menangani awal (TPTKP) terhadap pelanggaran

5) Melaporan dan menangani kejadian dan panggilan/permintaan bantuan satpam, termasuk konsep, pemasangandan memelihara sistem alaram 
11. Office girl PT.(SBS) Sinar Bengkulu Selatan

Bertugas sebagai membersihkan ruangag lingkup yang ada di PT.(SBS)

Sinar Bengkulu Selatan agar tetap terliahat rapi dan nyaman.

12. Assisten sortasi PT.(SBS) Sinar Bengkulu Selatan

1) Bertanggung jawab terhadap kegiataan sortir tandan buah segar kelapa sawit

2) Menjamin bahwa semua buah sawit yang digunakan dalam proses sesuai dengan kreteria yang ditetapkan

3) Mengawasi pemakaiaan bahan-bahan laboratorium dan bahan-bahan pembantu selama proses pengelohan berlansung

4) Mengawasi kondisi TBS yang masuk dan memastikan jumlah TBS yang masuk pabrik sesuai dengan SPB dari tiap-tiap truck untuk menetukan kapasitas olah, dan perhitungan rendamen bersama dengan assisten pengolahan

5) Mengawasi pemeriksaan limbah pabrik dari hasil kegiataan produksi pabrik maupun kegitaaan-kegitaan lain dan pengaruhnya terhadap lingkungan sekitar

6) Mengawasi jumlah pengeluaran hasil produksi CPO

13. Assiten produksi PT.(SBS) Sinar Bengkulu Selatan

1) Merencanakan jadwal pengelohan sesuai dengan estimasi buah yang akan diterima

2) Merencanakan penggunaan jumlah tenaga kerja yang diperlukan dalam proses produksi 
3) Bertanggung jawab atas tercapainya target dan kualitas produk yang dihasilkan

14. Assiten maintennance PT.(SBS) Sinar Bengkulu Selatan

1) Melaksanakan seluruh program kegiatan/pekerjaan pemeliharaan dan perawatan unit mesin-mesin utama serta mesin pendukung pengelohan buah sawit yang telah ditetapkan

2) Mengawasi dan mengendalikan seluruh aspek pelaksanaan perawatan dan perbaikan unit mesin pengeolahan termasuk pengawasan dan pengendalian waktu dan biaya dengan tetap memperhatikan aspek teknis

15. Kepala laboraturium PT.(SBS) Sinar Bengkulu Selatan

1) Menjamin bahwa kebijaksanaan mutu dipahami petugas lab diseluruh tingkat organisasi laboraturium dan sortasi

2) Membuat rencana pemakiaan bahan-bahan serta alat yang di berhubungan dengan analisa laboraturium dan sortasi untuk disampaikan kepada kepala pengeolahan setelah disetujui ADM

3) Menajamin bahwa pemeriksaan dan pengujiaan pada penerima TBS dalam proses dan produk akhir telah dilaksanakan sesuai dengan prosedur dan catatan mutu yang ditelah ditetapakan

4) Menyetujui laporan hasil pemeriksaan dan pengujiaan pada penerima bahan baku pada awal maupun produk akhir 


\subsection{Karakteristik responden}

Responden yang menjadi subjek pada penelitian ini Pada PT.(SBS) Sinar Bengkulu Selatan. Dari hasil pengumpulan data melalui koesioner terhadap 95 orang yang dijadikan responden penelitian, maka dapat diketahui karakteristik responden berdasarkan jenis kelamin, usia, dan pendidikan terakhir.

\subsubsection{Karakteristik Responden Berdasarkan Jenis Kelamin}

Jumlah responden berdasarkan jenis kelamin yang ada pada Pada PT.(SBS) Sinar Bengkulu Selatan dapat dilihat pada tabel 4.1

Tabel 4.1

Karakteristik Responden Berdasarkan jenis Kelamin

\begin{tabular}{|c|c|c|}
\hline Jenis Kelamin & Frekuensi & Persentase \\
\hline Laki-laki & 75 & $88.23 \%$ \\
\hline Perempuan & 20 & $17.77 \%$ \\
\hline Total & 95 & $100 \%$ \\
\hline
\end{tabular}

Sumber: Data yang diolah 2019

Berdasarkan tabel 4.1 di atas diketahui karakteristik responden berdasarakan jenis kelamin laki-laki sebanyak 75 orang responden atau $88.23 \%$ dan perempuan sebanyak 20 orang responden atau $17.77 \%$. Dari data tersebut menyatakan bahwa Pada PT.(SBS) Bengkulu Selatan lebih banyak laki-laki dari perempuan yang berkerja pada PT.(SBS) Sinar Bengkulu Selatan.

\subsubsection{Karakteristik Responden Berdasarkan Usia}

Jumlah responden berdasarkan usia yang ada pada Pada PT.(SBS) Sinar Bengkulu Selatan dapat dilihat pada tabel 4.2 
Tabel 4.2

Karakteristik Responden Berdasarkan Usia

\begin{tabular}{|c|c|c|}
\hline Usia & Frekuensi & Persentase \\
\hline $20-29$ & 27 & $28,4 \%$ \\
\hline $30-39$ & 32 & $33,6 \%$ \\
\hline $40-49$ & 36 & $38 \%$ \\
\hline Total & 95 & $100 . \%$ \\
\hline
\end{tabular}

Sumber: Data yang diolah 2019

Berdasarkan tabel 4.2 Diketahui karakteristik responden berdasarkan usia yang paling mendominasi usia 40-49 responden dengan persentase $38 \%$. Dari data tersebut menyatakan bahwa Pada PT.(SBS) Sinar Bengkulu Selatan yang paling banyaknya diumur tersebut dapat menunjukan dengam banyaknya karyawan dapat mendirikan suatu usaha yang sudah memiliki pengalaman yang lebih banyak.

\subsubsection{Karakteristik Responden Berdasarkan Pendidikan Terakhir}

Jumlah responden berdasarkan pendidikan terakhir yang ada pada Pada PT.(SBS) Sinar Bengkulu Selatan dapat dilihat pada tabel 4.3

Tabel 4.3

Karakteristik Responden Berdasarkan jenis Kelamin

\begin{tabular}{|c|c|c|}
\hline Pendidikan Terakhir & Frekuensi & Persentase \\
\hline SMA & 60 & $63,2 \%$ \\
\hline DIII & 15 & $15,7 \%$ \\
\hline S1 & 20 & $21,1 \%$ \\
\hline Total & 95 & $100 \%$ \\
\hline
\end{tabular}

Sumber: Data yang diolah 2019 
Berdasarkan tabel 4.3 di atas diketahui karakteristik responden berdasarakan pendidikan terakhir sebnayak SMA 60 Responden dengan presentasi 63,2\%, DIII Sebanyak 15 responden dengan presentasi 15,7\% dan S1 sebnayak 20 responden dengan presentasi 21,1\%. Hal ini menunjukan bahwa karyawan pada PT.(SBS) Sinar Bengkulu Selatan masih banyak yang berpendidikan rendah.

\subsection{Analisis Deskriptif}

\subsubsection{Tanggapan Responden Terhadap Variabel Kompensasi $\left(\mathrm{X}_{1}\right)$}

Pada variabel Kompensasi penilaian dilakukan dengan empat Indikator, Adapun tanggapan responden terhadap variabel Kompensasi adalah sebagai berikut:

Table 4.4

Tanggapan Responden

Terhadap Variabel Kompensasi $\left(\mathrm{X}_{1}\right)$

\begin{tabular}{|l|l|c|c|c|c|c|c|c|}
\hline \multirow{2}{*}{ No } & \multicolumn{1}{|c|}{ Pernyataan } & \multicolumn{5}{|c|}{ Penilaian } & \multirow{2}{*}{ Jumlah } & $\begin{array}{c}\text { Rata } \\
\text {-rata }\end{array}$ \\
\cline { 3 - 7 } & & STS & T & N & S & SS & & \\
\hline 1 & $\begin{array}{l}\text { Saya mendapatkan gaji } \\
\text { atas pekerjaan saya setiap } \\
\text { bulan secara tepat waktu }\end{array}$ & & 7 & 34 & 40 & 14 & 346 & 3.64 \\
\hline 2 & $\begin{array}{l}\text { Gaji yang diberikan sesuai } \\
\text { dengan harapan saya }\end{array}$ & & 4 & 34 & 38 & 19 & 357 & 3.76 \\
\hline 3 & $\begin{array}{l}\text { Perusahaan memberikan } \\
\text { upah kepada saya apabila } \\
\text { hasil kerja saya mencapai } \\
\text { atau melebihi target yang } \\
\text { telah ditetapkan }\end{array}$ & & 6 & 37 & 30 & 22 & 353 & 3.72 \\
\hline 4 & $\begin{array}{l}\text { Upah yang diberikan } \\
\text { perusahaan sebanding }\end{array}$ & & 4 & 27 & 47 & 17 & 362 & 3.81 \\
\hline
\end{tabular}




\begin{tabular}{|c|c|c|c|c|c|c|c|c|}
\hline & $\begin{array}{l}\text { dengan waktu kerja } \\
\text { lembur }\end{array}$ & & & & & & & \\
\hline 5 & $\begin{array}{l}\text { Insentif yang diberikan } \\
\text { sesuai dengan tanggung } \\
\text { jawab yang dilimpahkan } \\
\text { oleh perusahaan kepada } \\
\text { saya }\end{array}$ & & 1 & 22 & 47 & 25 & 381 & 4.01 \\
\hline 6 & $\begin{array}{l}\text { Saya menerima insentif } \\
\text { (bonus berupa uang dan } \\
\text { piagam dan penghargaan }\end{array}$ & & 3 & 34 & 36 & 22 & 362 & 3.81 \\
\hline 7 & $\begin{array}{l}\text { Perusahaan memberikan } \\
\text { tunjangan asuransi } \\
\text { keluarga bagi karyawan }\end{array}$ & 2 & 4 & 35 & 32 & 22 & 353 & 3.72 \\
\hline 8 & $\begin{array}{l}\text { Perusahaan memberikan } \\
\text { tunjangan cuti bagi } \\
\text { karyawan }\end{array}$ & & 6 & 34 & 37 & 18 & 352 & 3.71 \\
\hline 9 & $\begin{array}{l}\text { Perusahaan } \\
\text { memperhatikan } \\
\text { pemenuhan kebutuhan dan } \\
\text { fasilitas yang ada di } \\
\text { kantor }\end{array}$ & & 3 & 30 & 44 & 18 & 362 & 3.81 \\
\hline 10 & $\begin{array}{l}\text { Saya menerima fasilitas } \\
\text { kantor yang memadai }\end{array}$ & 2 & 4 & 41 & 36 & 12 & 337 & 3.55 \\
\hline \multicolumn{8}{|c|}{ Rata-rata } & 3.75 \\
\hline
\end{tabular}

Sumber: Data yang diolah 2019

Adapun hasil analisis penilaian responden pada tabel 4.4 Terhadap variabel Kompensasi $\left(\mathrm{X}_{1}\right)$ memiliki nilai rata-rata tertinggi yaitu 4.01 dan indikator terendah dengan rata-rata yaitu 3.55. Variabel Kompensasi menghasilkan nilai rata-rata sebesar 3.75,. Menunjukan bahwa rata-rata pernyataan penilaian responden mengenai variabel Kompensasi adalah pada kategori baik. 


\subsubsection{Tanggapan Responden Terhadap Variabel Disiplin Kerja $\left(\mathrm{X}_{2}\right)$}

Pada variabel Disiplin Kerjapenilaian dilakukan dengan tujuh Indikator, Adapun tanggapan responden terhadap variabel Disiplin Kerja adalah sebagai berikut:

Table 4.5

Tanggapan Responden

Terhadap Variabel Disiplin Kerja $\left(\mathrm{X}_{2}\right)$

\begin{tabular}{|l|l|c|c|c|c|c|c|c|}
\hline \multirow{2}{*}{ No } & \multicolumn{1}{|c|}{ Pernyataan } & \multicolumn{3}{|c|}{ Peniliaian } & \multirow{2}{*}{ Jumlah } & $\begin{array}{c}\text { Rata- } \\
\text { rata }\end{array}$ \\
\cline { 3 - 7 } & & STS & TS & N & S & SS & & 3.58 \\
\hline & $\begin{array}{l}\text { Saya selalu datang ke } \\
\text { tempat kerja sebelum } \\
\text { jam kerja dimulai }\end{array}$ & & 3 & 46 & 34 & 12 & 340 & \\
\hline 2 & $\begin{array}{l}\text { Saya tidak } \\
\text { meninggalkan kantor } \\
\text { pada saat jam kerja }\end{array}$ & & 5 & 34 & 40 & 16 & 352 & 3.71 \\
\hline 3 & $\begin{array}{l}\text { Saya bekerja sesuai } \\
\text { dengan prosedur yang } \\
\text { telah ditentukan } \\
\text { perusahaan }\end{array}$ & & 3 & 35 & 38 & 19 & 358 & 3.77 \\
\hline 4 & $\begin{array}{l}\text { Saya mengenakan } \\
\text { pakaiaan sesuai dengan } \\
\text { peraturan perusahaan }\end{array}$ & & 1 & 29 & 50 & 15 & 364 & 3.83 \\
\hline 5 & $\begin{array}{l}\text { Saya melakukan } \\
\text { pekerjaan sesuai } \\
\text { dengan jam kerja yang } \\
\text { ditentukan perusahaan }\end{array}$ & & 5 & 33 & 35 & 22 & 359 & 3.78 \\
\hline 6 & $\begin{array}{l}\text { Saya selalu teliti dalam } \\
\text { bekerja }\end{array}$ & & 46 & 18 & 363 & 3.82 \\
\hline 7 & $\begin{array}{l}\text { Saya selalu berhati-hati } \\
\text { dalam menggunakan }\end{array}$ & & & & & & & \\
\hline & & & & & & & & \\
\hline
\end{tabular}




\begin{tabular}{|l|l|l|l|l|l|l|l|l|}
\hline & peralatan perusahaan & & & & & & & \\
\hline 8 & $\begin{array}{l}\text { Saya selalu bersikap } \\
\text { sopan selama berada di } \\
\text { perusahaan }\end{array}$ & 2 & 4 & 35 & 32 & 22 & 353 & 372 \\
\hline 9 & $\begin{array}{l}\text { Saya selalu memiliki } \\
\text { etika yang baik selama } \\
\text { berada di perusahaan }\end{array}$ & 2 & 4 & 42 & 39 & 8 & 332 & 3.49 \\
\hline Rata-rata & & & & & & 3.75 \\
\hline
\end{tabular}

Sumber: Data yang diolah 2019

Adapun hasil analisis penilaian responden pada tabel 4.5 Terhadap variabel Disiplin Kerja $\left(\mathrm{X}_{1}\right)$ (Disiplin Kerja dilakukan secara langsung kepada konsumen sehingga konsumen benar-benar mengetahui pelayanan yang lebih baik) dengan rata-rata tertinggi yaitu 4.04 dan indikator Disiplin Kerja memiliki rata-rata terendah yaitu 3,49. Variabel Disiplin Kerja menghasilkan nilai rata-rata sebesar 3.75. Menunjukan bahwa rata-rata pernyataan penilaian responden mengenai variabel Disiplin Kerja adalah pada kategori baik

\subsubsection{Tanggapan Responden Terhadap Variabel Kinerja Karyawan (Y)}

Pada variabel Kinerja Karyawan penilaian dilakukan dengan lima Indikator. Adapun tanggapan responden terhadap variabel Kinerja Karyawan adalah sebagai beriku : 
Table 4.6

Tanggapan Responden

Terhadap Variabel Kinerja Karyawan (Y)

\begin{tabular}{|c|c|c|c|c|c|c|c|c|}
\hline \multirow[b]{2}{*}{ No } & \multirow[b]{2}{*}{ Pernyataan } & \multicolumn{5}{|c|}{ Peniliaian } & \multirow[b]{2}{*}{ Jumlah } & \multirow{2}{*}{$\begin{array}{l}\text { Rata } \\
\text {-rata }\end{array}$} \\
\hline & & STS & TS & $\mathrm{N}$ & $S$ & $\begin{array}{l}\mathrm{S} \\
\mathrm{S}\end{array}$ & & \\
\hline 1 & $\begin{array}{l}\text { Saya mengerjakan suatu } \\
\text { pekerjaan dengan baik }\end{array}$ & & 1 & 32 & 47 & $\begin{array}{l}1 \\
5\end{array}$ & 364 & 3.83 \\
\hline 2 & $\begin{array}{l}\text { Skill yang saya miliki } \\
\text { sesuai dengan pekerjaan } \\
\text { yang saya lakukan }\end{array}$ & & 8 & 32 & 47 & 8 & 340 & 3.58 \\
\hline 3 & $\begin{array}{l}\text { Tingkat pencapaiaan } \\
\text { volume kerja yang saya } \\
\text { hasilkan telah sesuai } \\
\text { dengan harapan } \\
\text { perusahaan }\end{array}$ & & 1 & 22 & 46 & $\begin{array}{l}2 \\
6\end{array}$ & 382 & 4.02 \\
\hline 4 & $\begin{array}{l}\text { Perusahaan menetapkan } \\
\text { target kerja yang penuh } \\
\text { perhitungan }\end{array}$ & & 2 & 25 & 46 & $\begin{array}{l}2 \\
2\end{array}$ & 373 & 3.93 \\
\hline 5 & $\begin{array}{l}\text { Saya menguasai pekerjaan } \\
\text { yang sedang saya jalani }\end{array}$ & 1 & 4 & 32 & 41 & $\begin{array}{l}1 \\
7\end{array}$ & 354 & 3.73 \\
\hline 6 & $\begin{array}{l}\text { Pekerjaan yang saya } \\
\text { lakukan sudah mencapai } \\
\text { target perusahaan }\end{array}$ & 2 & 4 & 34 & 32 & $\begin{array}{l}2 \\
3\end{array}$ & 355 & 3.74 \\
\hline 7 & $\begin{array}{l}\text { Saya merasa mempunyai } \\
\text { tanggung jawab terhadap } \\
\text { pekerjaan yang } \\
\text { dibebankan kepada saya }\end{array}$ & 1 & 5 & 36 & 34 & $\begin{array}{l}1 \\
9\end{array}$ & 350 & 3.68 \\
\hline 8 & $\begin{array}{l}\text { Saya dapat menyelesaikan } \\
\text { pekerjaan lebih dari yang } \\
\text { ditargetkan }\end{array}$ & 2 & 4 & 41 & 38 & $\begin{array}{l}1 \\
0\end{array}$ & 335 & 3.53 \\
\hline Rat & ta & & & & & & & 3,75 \\
\hline
\end{tabular}

Sumber: Data yang diolah 2019

Adapun hasil analisis penilaian responden pada tabel 4.6 Terhadap variabel

Kinerja Karyawan (Y) (perusahaan dalam satu tahun ini selalu mengalami 
peningkatan penjualan, setelah melakukan pengembangan Kinerja Karyawan) memiliki rata-rata tertinggi yaitu 4.02, dan memiliki rata-rata terendah yaitu 3.53. Dengan variabel kinerja pembelian menghasilkan nilai rata-rata sebesar 3.75. Menunjukan bahwa rata-rata pernyataan penilaian responden mengenai variabel Kinerja Karyawan adalah pada kategori baik.

\subsection{Uji Asumsi Klasik}

\subsubsection{Uji Asumsi Klasik Normalitas}

Pada tabel test of normality dengan mengunakan kolmogorov-smirnov nilai sig $>0,05$, bisa dilihat bahwa data berdistribusi normal :

\section{Gambar 4.1}

\section{Grafik histrogram uji normalitas}

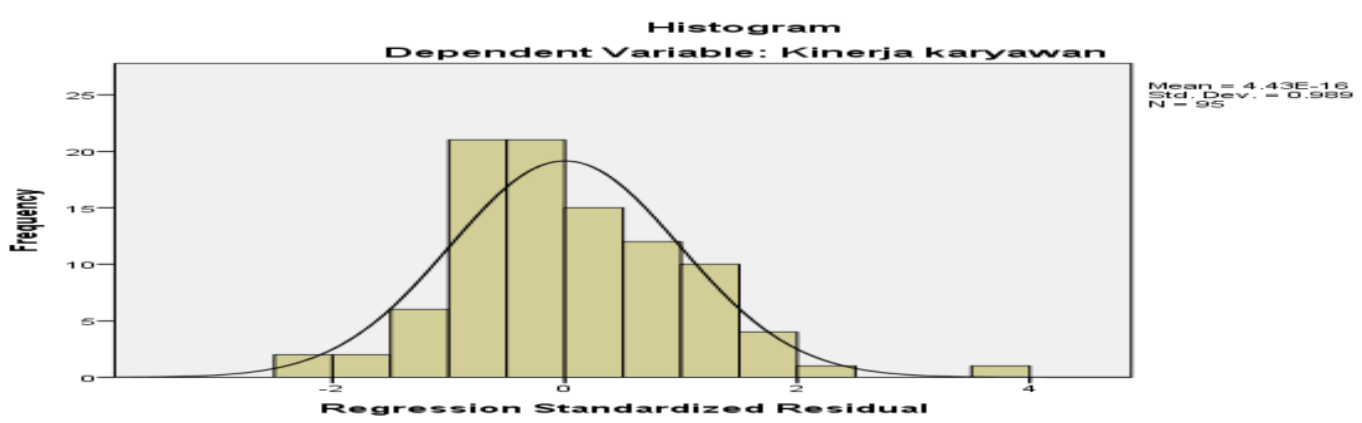

Kompensasi $\left(\mathrm{X}_{1}\right)$ dan Disiplin Kerja $\left(\mathrm{X}_{2}\right)$ terhadapa Kinerja Karyawan(Y)

Gambar 4.1 menunjukan bahwa grafik uji nomarlitas mengambarkan penyebaran data disekitar garis diagonal dan penyebarannya mengikuti arah garis diagonalgrafik tersebut, makamodel regresi yang digunakan dalam penelitian ini memenuhi asumsi normalitas. 


\subsubsection{Uji Asumsi Klasik Heterokedasitas}

Uji heterokedasitas bertujuan untuk menguji apakah dalam model regresi terjadi ketidak sama varians. Adapun hasil uji statistic heterokedasitas yang diperoleh dalam penelitian ini adalah sebagai berikut :

\section{Gambar 4.2}

\section{Uji penyimpangan Heteroskedasitas}

Antara Variabel - Variabel Kompensasi $\left(\mathrm{X}_{1}\right)$ dan Disiplin Kerja $\left(\mathrm{X}_{2}\right)$ terhadapa Kinerja Karyawan (Y)

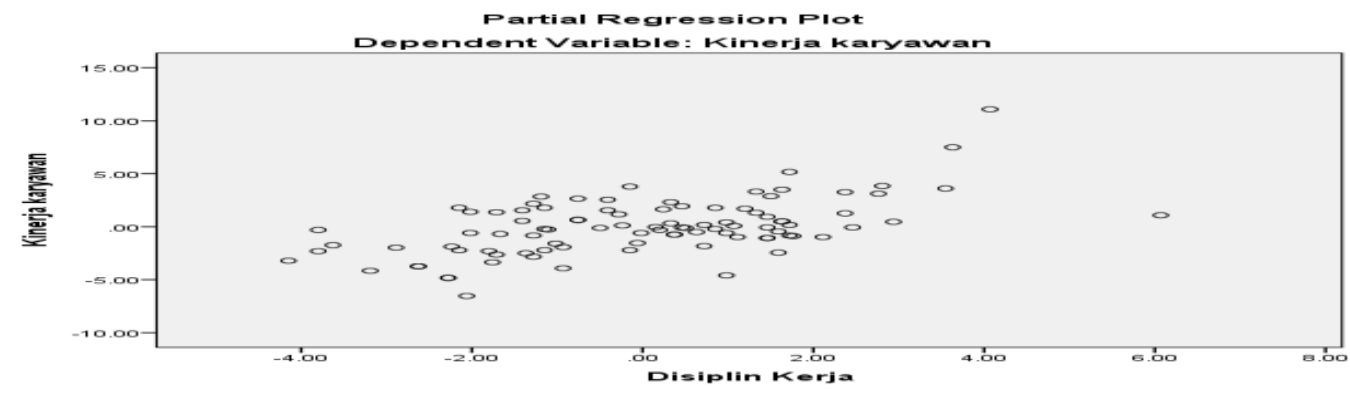

Grafik scatterplot yang ditampilkan untuk uji heterokesdastisitas menampakan titik-titik yang menyebar secara acak dan tidak ada pola yang jelas terbentuk serta dalam penyebaran titik-titik tersebut menyebar dibawah dan diatas angka 0 pada sumbu Y. Hal tersebut mengindentifikasikan tidak terjadinya heterokesdastisitas pada model regresi, sehinga model regresi layak dipakai untuk memprediksi variabel Kinerja Karyawan (Y) 


\subsubsection{Uji Asumsi Klasik Multikoleritas}

Uji multikolineritas ini bertujuan untuk mengetahui apakah tiap-tiap variabel bebas yaitu Kompensansi dan Disiplin Kerja, saling berhubungan secara linier. Pengujian adanya multikoleritas ini dapat dilakukan dengan melihat nilai tolenrasi diatas 0,1 dan vif nya lebih kecil dari 10 tidak ada kecendrungan terjadi gejala multikoliner. Pengujian multikolonieritas mengunakan software spss versi 2.4 dapat dilihat pada tabel dibawah ini :

\section{Tabel 4.7}

Uji multikolinieritas antara Kompensasi $\left(\mathrm{X}_{1}\right)$ dan Disiplin Kerja $\left(\mathrm{X}_{2}\right)$ dengan variabel Kinerja Karyawan (Y)

\begin{tabular}{|l|l|c|c|c|}
\hline No & \multicolumn{1}{|c|}{ Variabel } & Tolerance & VIF & Keterangan \\
\hline 1 & Kompensasi & 0.183 & 5.464 & Non Multikolinieritas \\
\hline 2 & Disiplin Kerja & 0.183 & 5.464 & Non Multikolinieritas \\
\hline
\end{tabular}

Sumber Penelitian 2019

Berdasarkan Tabel 4.7 diatas terlihat bahwa semua variabel mempunyai nilai toleransi diatas 0,1 dan nilai VIF dibawah 10 , dengan demikian dapat disimpulkan bahwa variabel pada penelitian ini bebas multikolinieritas 


\subsubsection{Analisis Korelasi Parsial $\left(\mathrm{X}_{1}-\mathrm{Y}\right)$}

Tabel 4.8

Hasil Nilai Korelasi Parsial $\left(\mathrm{X}_{1}-\mathrm{Y}\right)$

\begin{tabular}{|l|l|r|r|}
\hline \multicolumn{2}{|c|}{} & Kompensasi & Kinerja Karyawan \\
\hline Kompensasi & Pearson Correlation & 1 & .823 \\
\cline { 2 - 4 } & Sig. (2-tailed) & & .000 \\
\cline { 2 - 4 } & N & 95 & 95 \\
\hline Kinerja Karyawan & Pearson Correlation & $.644^{* \prime}$ & 1 \\
\cline { 2 - 5 } & Sig. (2-tailed) & .000 & 95 \\
\cline { 2 - 5 } & N & 95 & \\
\cline { 2 - 5 } & & & \\
\end{tabular}

${ }^{\star \star}$. Correlation is significant at the 0.01 level (2-tailed).

Berdasarkan tabel 4.8 di atas diperoleh nilai (R) produk moment sebesar 0,823 yang berarti korelasi parsial hubungan antara variabel independent Kompensasi $\mathrm{X}_{1}$ terhadap variabel dependent Kinerja Karyawan $\mathrm{Y}$ termasuk kategori Tinggi.

\subsubsection{Analisis Korelasi Parsial $\left(\mathrm{X}_{2}-\mathrm{Y}\right)$}

Tabel 4.9

Hasil Nilai Korelasi Parsial $\left(\mathrm{X}_{2}-\mathrm{Y}\right)$

Correlations

\begin{tabular}{|l|l|r|r|}
\hline \multicolumn{2}{|c|}{} & Kinerja Karyawan & Disiplin Kerja \\
\hline Disiplin Kerja & Pearson Correlation & 1 & .926 \\
\cline { 2 - 4 } & Sig. (2-tailed) & & .000 \\
\cline { 2 - 4 } & N & 95 & 95 \\
\hline Kenerja Karyawan & Pearson Correlation & .644 & \\
\cline { 2 - 4 } & Sig. (2-tailed) & .000 & \\
\cline { 2 - 4 } & N & 95 & 95 \\
\hline
\end{tabular}


${ }^{\star *}$. Correlation is significant at the 0.01 level (2-tailed).

Berdasarkan tabel 4.9 di atas diperoleh nilai $(\mathrm{R})$ produk moment sebesar 0,926 yang berarti korelasi parsial hubungan antara variabel independent Disiplin Kerja $\mathrm{X}_{2}$ terhadap variabel dependent Kinerja Karyawan (Y) termasuk kategori tinggi.

\subsection{Analisis Regresi Linear Berganda}

Analisis regresi linear berganda yang akan dibahas dalam penelitian ini sehingga penulis bisa menggambarkan mengenai tanggapan responden (Kompensasi dan Disiplin Kerja) terhadap Kinerja Karyawan pada Pada PT.(SBS) Sinar Bengkulu Selatan. Berdasarkan estemasi regresi linier berganda dengan menggunakan program SPSS Versi 24,0 For Windows,maka diperoleh tabel dibawah ini :

Tabel 4.10

Hasil Analisis Regresi Linear Berganda

\begin{tabular}{|c|c|c|c|c|c|c|}
\hline \multicolumn{7}{|c|}{ Coefficients $^{a}$} \\
\hline & & \multicolumn{2}{|c|}{$\begin{array}{l}\text { Unstandardized } \\
\text { Coefficients }\end{array}$} & \multirow{2}{*}{$\begin{array}{c}\begin{array}{c}\text { Standardized } \\
\text { Coefficients }\end{array} \\
\text { Beta }\end{array}$} & \multirow[b]{2}{*}{$t$} & \multirow[b]{2}{*}{ Sig. } \\
\hline \multicolumn{2}{|c|}{ Model } & B & Std. Error & & & \\
\hline \multirow[t]{3}{*}{1} & (Constant) & 14.876 & 1.866 & & 7.972 & .000 \\
\hline & Kompensasi & .277 & .115 & .405 & 2.404 & .018 \\
\hline & Disiplin Kerja & .795 & .120 & 1.067 & 6.330 & .000 \\
\hline
\end{tabular}

a. Dependent Variable: Kinerja Karyawan

Sumber: Output SPSS 24,0 
Dari perhitungan hasil diatas didapatkan persamaan regresinya adalah sebagai berikut :

$\mathrm{Y}=14.876+0.277\left(\mathrm{X}_{1}\right)+0.795\left(\mathrm{X}_{2}\right)$

Berdasarkan persamaan regresi diatas, maka dapat dijelaskan sebagai berikut :

1. Nilai Konstanta 14.876 mempunyai arti bahwa apabila variabel Kompensasi $\left(\mathrm{X}_{1}\right)$, Disiplin Kerja $\left(\mathrm{X}_{2}\right)$ terhadap Kinerja Karyawan $(\mathrm{Y})$ sama dengan nol, maka variabel Kinerja Karyawan akan tetap yaitu 14.876 apabila variabel Kompensasi $\left(\mathrm{X}_{1}\right)$ dan Disiplin Kerja $\left(\mathrm{X}_{2}\right)$ sama dengan nol.

2. Koefisien Regresi $X_{1}$, sebesar 0.277 mempunyai makna jika nilai variabel Kompensasi $\left(\mathrm{X}_{1}\right)$ naik satu satuan maka nilai Kinerja Karyawan (Y) akan naik sebesar 0.277 dengan asumsi variabel Disiplin Kerja $\left(\mathrm{X}_{2}\right)$ dianggap tetap.

3. Koefisien Regresi $X_{2}$, sebesar 0.795 mempunyai makna jika nilai variabel Disiplin Kerja $\left(\mathrm{X}_{2}\right)$ naik satu satuan maka nilai variabel Kinerja Karyawan (Y) akan naik sebesar 0.795 dengan asumsi variabel Kompensasi $\left(\mathrm{X}_{1}\right)$ dianggap tetap.

4. Hasil penelitian dalam penelitian yang paling dominan mempengaruhi variable Kinerja Karyawan $(\mathrm{Y})$ adalah Variabel Kompensasi $\left(\mathrm{X}_{1}\right)$ adalah sebesar 0.795 dan Variabel Disiplin Kerja $\left(\mathrm{X}_{2}\right)$ adalah sebesar 0.277. 


\subsection{Koefisisen Determinasi $\left(R^{2}\right)$}

Untuk mengetahui besarnya presentase sumbangan pengaruh variabel bebas Kompensasi $\left(\mathrm{X}_{1}\right)$ dan Disiplin Kerja $\left(\mathrm{X}_{2}\right)$ terhadap variabel terikat Kinerja Karyawan (Y) maka dari perhitungan komputer menggunakan SPSS 24,0 didapatkan uji koefisien determinasi dapat dilihat pada table sebagai berikut:

Tabel 4.11

Nilai Koefisien Determinasi $\left(\mathrm{R}^{2}\right)$

\begin{tabular}{|c|c|c|c|c|}
\hline \multicolumn{5}{|c|}{ Model Summary } \\
\hline Model & $\mathrm{R}$ & R Square & Adjusted R Square & Std. Error of the Estimate \\
\hline 1 & $.722^{\mathrm{a}}$ & .521 & .511 & 2.21032 \\
\hline \multicolumn{5}{|c|}{ a. Predictors: (Constant), Disiplin Kerja, Kompensasi } \\
\hline
\end{tabular}

Sumber: Output SPSS 24,0

Berdasarkan tabel 4.11 diatas dapat diketahui nilai koefisien determinasi Adjusted $\left(\mathrm{R}^{2}\right)$ diperoleh nilai sebesar 0.521 (Sugiyono, 2013). Nilai ini mempunyai arti bahwa variabel Kompensasi dan Disiplin Kerja terhadap variabel Kinerja Karyawan memberikan sumbangan sebesar 0.521 atau $52.51 \%$ terhadap Kinerja Karyawan pada Pada PT.(SBS) Sinar Bengkulu Selatan sedangkan sisanya sebesar 0.470 atau $47.9 \%$ dipengaruhi oleh variabel lain yang tidak masuk dalam model penelitian ini. 


\subsection{Uji Hipotesis}

\subsubsection{Pengujian Hipotesis Dengan Uji t}

Untuk menguji pengaruh variabel bebas secara parsial terhadap variabel terikat digunakan uji $\mathrm{t}$ dapat dilihat pada table sebagai berikut :

Tabel 4.12

Hasil Pengujian Hipotesis dengan Uji t

\begin{tabular}{|c|c|c|c|c|c|c|}
\hline \multicolumn{7}{|c|}{ Coefficients $^{a}$} \\
\hline & & \multicolumn{2}{|c|}{$\begin{array}{l}\text { Unstandardized } \\
\text { Coefficients }\end{array}$} & \multirow{2}{*}{$\begin{array}{c}\begin{array}{c}\text { Standardized } \\
\text { Coefficients }\end{array} \\
\text { Beta }\end{array}$} & \multirow[b]{2}{*}{$\mathbf{T}$} & \multirow[b]{2}{*}{ Sig. } \\
\hline \multicolumn{2}{|c|}{ Model } & B & Std. Error & & & \\
\hline \multirow[t]{3}{*}{1} & (Constant) & 14.876 & 1.866 & & 7.972 & .000 \\
\hline & Kompensasi & .277 & .115 & .405 & 2.404 & .018 \\
\hline & Disiplin Kerja & .795 & .120 & 1.067 & 6.330 & .000 \\
\hline & $\mid \mathbf{b l}$ & IW & & & & \\
\hline
\end{tabular}

Sumber: Output SPSS 24.0 (lampiran 5)

Melalui perhitungan yang dilakukan dengan menggunakan program SPSS, maka perbandingan antara $t_{\text {hit }}$ dengan $t_{a / 2}(n-k-1)=95-2-1=92(1.9860)$ setiap variabel sebagai berikut :

1. Kompensasi yaitu $t_{\text {hit }}>t_{\alpha / 2}(2.404>1.9860)$ dan $(\operatorname{sig} \alpha=0,018<0,050)$, hal tersebut menyatakan bahwa adanya pengaruh yang signifikan Kompensasi $\left(\mathrm{X}_{1}\right)$ terhadap Kinerja Karyawan pada Pada PT.(SBS) Sinar Bengkulu Selatan.

2. Berdasarkan uji $t_{\text {hit }}$ untuk variabel Disiplin Kerja $\left(X_{2}\right)$ yaitu $t_{h i t}>t_{\alpha / 2}(6.330$ $>1.9860)$ dan $(\operatorname{sig} \alpha=0,000<0,050)$, hal tersebut menyatakan bahwa 
adanya pengaruh yang signifikan Disiplin Kerja terhadap Kinerja Karyawan pada Pada PT.(SBS) Sinar Bengkulu Selatan.

3. Dari hasil penelitian variable yang dominan adalah Variabel Displin Kerja $\left(\mathrm{X}_{2}\right)$ sebesar 6.330 dan variable Kompensansi $\left(\mathrm{X}_{2}\right)$ sebesar 2.404.

\subsubsection{Pengujian Hipotesis Dengan Uji F}

Untuk menguji pengaruhh variabel bebas secara parsial terhadap variabel terikat digunakan uji F sebagai berikut :

Tabel 4.13

Hasil Pengujian Hipotesis dengan Uji F

\begin{tabular}{|c|c|c|c|c|c|c|}
\hline \multicolumn{7}{|c|}{ ANOVA $^{a}$} \\
\hline \multicolumn{2}{|c|}{ Model } & \multirow{2}{*}{$\begin{array}{r}\text { Sum of Squares } \\
489.438\end{array}$} & \multirow{2}{*}{$\begin{array}{r}\text { Df } \\
2\end{array}$} & \multirow{2}{*}{$\begin{array}{r}\text { Mean Square } \\
244.719\end{array}$} & \multirow{2}{*}{$\begin{array}{l}F \\
50.091\end{array}$} & \multirow{2}{*}{$\begin{array}{l}\text { Sig. } \\
.000^{\mathrm{b}}\end{array}$} \\
\hline 1 & Regression & & & & & \\
\hline & Residual & 449.467 & 92 & 4.886 & & \\
\hline & Total & 938.905 & 94 & & & \\
\hline \multicolumn{7}{|c|}{ a. Dependent Variable: Kinerja Karyawan } \\
\hline
\end{tabular}

Sumber: Output SPSS 24,0

Berdasarkan tabel uji hipotesis dengan uji $\mathrm{F}$ diatas diperoleh $\mathrm{F}_{\text {hitung }}$ sebesar 50.091 dengan nilai $\mathrm{F}_{\text {tabel }}$ sebesar 1.9855 yaitu $(50.091>1.9855)$ dan $(\operatorname{sig} \alpha=$ $0.000<0,050$ ), maka dengan demikian dapat disimpulkan bahwa $\mathrm{H}_{3}$ diterima artinya secara simultan variabel Kompensasi dan Disiplin Kerja berpengaruh yang signifikan terhadap Kinerja Karyawan di Pada PT.(SBS) Sinar Bengkulu Selatan. 


\subsection{Pembahasan Hasil Penelitian}

\subsubsection{Kinerja Karyawan pada PT.(SBS) Sinar Bengkulu Selatan}

hasil penelitiaan ini menyatakan bahwa kinerja karyawan sudah dikatakan baik. hal ini dapat lihat pada karyawan PT.(SBS) Sinar Bengkulu Selatan yang sudah melakukan pekerjaan yang secara tepat waktu serta tugas-tugas yang di limpahkan kepada karyawan sudah terlaksana dengan baik pada perusahaan PT.(SBS) Sinar Bengkulu Selatan sehingga kinerja karyawan sudah mulai meningkat di bandingkan dengan sebelumya. Kemudiaan dapat di lihat dari tanggapan responden, variabel Kinerja Karyawan (Y) berada pada kategori baik dengan nilai tertinggi 4.02 dan memilki terendah 3.53, maksudnya adalah kinerja karyawan pada PT.(SBS) Sinar Bengkulu Selatan sudah baik. Dilihat dari 1 (Saya melakukan pekerjaan dengan baik dan 2 (Skill yang saya milki sesuai dengan pekerjaan yang saya lakukan), artinya bahwa Setiap karyawan selalu melakukan pekerjaannya sesuai dengan target dan standar yang telah disepakati oleh pihak perusahaan.

\subsubsection{Kompensansi pada PT.(SBS) Sinar Bengkulu Selatan}

Hasil penelitian ini menyatakan bahwa kompensansi yang ada di perusahaan PT. (SBS) Sinar Bengkulu Selatan sudah di katakan baik. hal ini sebabkan oleh pemberiaan gaji dan insentif, serta tunjangan yang sudah di berikan secara tepat waktu sehingga kinerja karyawan yang ada di PT. (SBS) Sinar Bengkulu Selatan lebih meningkat dari sebelumnya dapat di lihat dari hasil tanggapan responden, variabel Kompensasi $\left(\mathrm{X}_{1}\right)$ dengan nilai tertinggi 4.01 dan nilai terendah 3.55 maksudnya adalah responden merasa sistem kompensasi di PT.(SBS) Sinar 
Benkulu Selatan sudah baik. Dari 10 item pernyataan, item pernyataan nomor 4 (Upah yang di berikan perusahaan sebanding dengan kerja lembur saya) memiliki skor tertinggi yaitu 4,01 dan item pernyataan dengan skor terendah adalah nomor 10 (Saya menerima fasilitas kantor yang memadai) memiliki skor 3,55.

\subsubsection{Displin Kerja Pada PT.(SBS) Sinar Bengkulu Selatan}

Hasil ini menunjukan bahwa displin kerja pada PT.(SBS) Sinar Bengkulu Selatan kategori baik. hal ini disebabkan pergantiaan pimpinan pada PT.(SBS) Sinar Bengkulu Selatan sangat mempengaruhi serta aturan-aturan baru yang di terapkan oleh pihak pimpinan PT.(SBS) Sinar Bengkulu Selatan sehingga kedispilanan yang ada di PT.(SBS) Sinar Bengkulu Selatan sudah di katakan baik dapat dilihat dari hasil tanggapan responden, variabel Disiplin Kerja (X2) berada pada kategori tinggi 4.04 dan yang terendah 3,49 maksudnya adalah responden merasa disiplin kerja karyawan PT.(SBS) Sinar Bengkulu Selatan sudah baik.

\subsubsection{Pengaruh Kompensansi Terhadap Kinerja karyawan}

Berdasarkan hasil penelitian dan pengolahan data yang dilakukan Pada PT.(SBS) Sinar Bengkulu Selatan melalui penyebaran kuesioner terhadap 95 orang responden yang telah diuji sehingga dapat diketahui pengaruh Kompensasi Terhadap Kinerja Karyawan pada Pada PT.(SBS) Sinar Bengkulu Selatan.

Dari analisis regresi linear berganda diperoleh persamaan $\mathrm{Y}=14.876+$ $0.277\left(\mathrm{X}_{1}\right)+$ angka ini mempunyai makna nilai konstanta 14.876 mempunyai arti bahwa variable kompensansi $\left(\mathrm{X}_{1}\right)$ terhadap kinerja karyawan $(\mathrm{Y})$ pada PT.(SBS) Sinar Bengkulu Selatan sama dengan nol, maka variable kinerja akan tetap yaitu, 14.876. hal ini berlaku saat dilaksanakan penelitiaan. Koefisien regresi variable 
kompensansi $\left(\mathrm{X}_{1}\right)$ sebesar 0,277 dan mempunyai makna bahwa apabila kompensansi $\left(\mathrm{X}_{1}\right)$ ditingkatkan, maka akan meningkatan kinerja karyawan (Y) pada PT.(SBS) Sinar Bengkulu Selatan.

Kompensasi memiliki pengaruh terhadap Kinerja Karyawan. Hal ini terlihat pada uji t yang menyatakan memiliki nilai $\left.t_{\text {hit }}>t_{\alpha / 2} 2.404>1.9860\right)$ dan $(\operatorname{sig} \alpha=$ $0,018<0,050)$, maka dari penelitian yang dilakukan dalam penelitian terdahulu menyatakan bahwa Kompensasi memiliki pengaruh positif dan signifikan terhadap Kinerja Karyawan.

Hasil penelitian ini sejalan dengan penelitiaan Andi Armansyah, Idris Azis, Niluh Putuh Evvy Rosssanty, (2018) dengan judul “pengaruh kompensanssi dan dsiplin kerja terhadap kinerja karyawan pada pegawai kantor BPJS kesehatan cabang palu", menyatakan bahwa kompensansi $\left(\mathrm{X}_{1}\right)$ berpengaruh positif dan signifikan terhadap kinerja karyawan (Y).

Hasil penelitian sejalan dengan penelitian Ali Wairooy (2017) dengan judul “pengaruh displin kerja dan kompensansi terhadap kinerja karyawan pada PT. Peetamina (persero), Tbk. Pemasaran region vii, menyatakan bahwa kompensansi $\left(\mathrm{X}_{1}\right)$ berpengaruh positif dan signifikan terhadap variable kinerja karyawan (Y).

Hasil penelitian ini sejalan dengan penelitian Putu Agus Candra Mahardika, Wayan Bagia, Ni Nyoman Yulianthini (2016), dengan judul "pengaruh kompensansi dan displin kerja terhadap kinerja karyawan pada hotel puri bagus lovina" menyatakan bahwa kompensansi $\left(\mathrm{X}_{1}\right)$ berpengaruh positif dan signifikan terhadapa variable kinerja karyawan (Y). 
Hasil penelitian ini sejalan dengan penelitian Dina Kurniati (2018), dengan judul "pengaruh kompensansi dan displin kerja terhadap kinerja karyawan di pt. Marinal indopirma desa kapedi sumenep menyatakan bahwa kompensansi $\left(\mathrm{X}_{1}\right)$ berpengaruh positif dan signifikan terhadap variable kinerja karyawan (Y).

the results of this study are in line with the research of Ilham Thaief, Aris Baharudin, Priyono \& Mohamad Syafi'i Idrus (2015) with the title "Effects of Training, Compensation on Employee Work Performance". which states compensation (X1) has a significant positive effect on employee performance (Y).

Hasil penelitiaan ini menolak dengan penelitiaan Ananta Dwikristianto Satedjo dan Sesilya Kempa (2015) dengan judul "pengaruh kompensansi dan displin kerja terhadap kinerja PT. Modern widya tehnical cabang jayapura” yang menyatakan bahwa kompensansi $\left(\mathrm{X}_{1}\right)$ berpengaruh negatif dan signifikan terhadap kinerja karyawan (Y) .

\subsubsection{Pengaruh Displin Kerja Terhadap Kinerja Karyawan}

Berdasarkan hasil penelitian dan pengolahan data yang dilakukan Pada karyawan PT.(SBS) Sinar Bengkulu Selatan melalui penyebaran kuesoner terhadap 95 orang responden yang telah diuji sehingga dapat diketahui pengaruh displin kerja Terhadap Kinerja Karyawan pada Pada PT.(SBS) Sinar Bengkulu Selatan

Dari analisis regresi linear berganda diperoleh persamaan $\mathrm{Y}=14.876+$ $0.795\left(\mathrm{X}_{2}\right)$ angka ini mempunyai makna nilai konstanta 14.876 mempunyai arti bahwa variable displin kerja $\left(\mathrm{X}_{2}\right)$ terhadap kinerja karyawan $(\mathrm{Y})$ pada PT.(SBS) Sinar Bengkulu Selatan sama dengan nol, maka variable kinerja akan tetap yaitu, 
14.876. hal ini berlaku saat dilaksanakan penelitiaan. Koefisien regresi variable kompensansi $\left(\mathrm{X}_{1}\right)$ sebesar 0,795 dan mempunyai makna bahwa apabila displin kerja $\left(\mathrm{X}_{2}\right)$ ditingkatkan, maka akan meningkatan kinerja karyawan (Y) pada PT.(SBS) Sinar Bengkulu Selatan.

Pengaru Displin kerja Kerja $\left(\mathrm{X}_{2}\right)$ Terhadap Kinerja Karyawan (Y)

Disiplin Kerja memiliki pengaruh terhadap Kinerja Karyawan. Hal ini terlihat pada uji $t$ yang menyatakan memiliki nilai nilai $t_{h i t}>t_{\alpha / 2}(6.330>1.9860)$ dan ( $\operatorname{sig} \alpha=0,000<0,050)$, maka $\mathrm{H}_{2}$ dalam penelitian ini dapat diterima. Hal ini sesuai dengan teori yang dikemukakan oleh Menurut Swastha (2000;245) mendefinisikan Disiplin Kerja yang baik dapat menjadi tolak ukur perusahaan dalam menciptakan Kinerja Karyawan yang maksimal, serta dalam penelitian terdahulu menyatakan bahwa Disiplin Kerja berpengaruh signifikan terhadap Kinerja Karyawan.

Hasil penelitian ini sejalan dengan penelitiaan Andi Armansyah, Idris Azis, Niluh Putuh Evvy Rosssanty, (2018) dengan judul “pengaruh kompensanssi dan dsiplin kerja terhadap kinerja karyawan pada pegawai kantor BPJS kesehatan cabang palu", menyatakan bahwa displin kerja $\left(\mathrm{X}_{2}\right)$ berpengaruh positif dan signifikan terhadap kinerja karyawan (Y).

Hasil penelitian sejalan dengan penelitian Ali Wairooy (2017) dengan judul “pengaruh displin kerja dan kompensansi terhadap kinerja karyawan pada PT. Peetamina (persero), Tbk. Pemasaran region vii, menyatakan bahwa Displin kerja $\left(\mathrm{X}_{2}\right)$ berpengaruh positif dan signifikan terhadap variable kinerja karyawan $(\mathrm{Y})$. 
Hasil penelitian ini sejalan dengan penelitian Putu Agus Candra Mahardika, Wayan Bagia, Ni Nyoman Yulianthini (2016), dengan judul "pengaruh kompensansi dan displin kerja terhadap kinerja karyawan pada hotel puri bagus lovina" menyatakan bahwa displin kerja $\left(\mathrm{X}_{2}\right)$ berpengaruh positif dan signifikan terhadapa variable kinerja karyawan (Y).

Hasil penelitian ini sejalan dengan penelitian Dina Kurniati (2018), dengan judul "pengaruh kompensansi dan displin kerja terhadap kinerja karyawan di pt. Marinal indopirma desa kapedi sumenep menyatakan bahwa displin kerja $\left(\mathrm{X}_{2}\right)$ berpengaruh positif dan signifikan terhadap variable kinerja karyawan (Y).

the results of this study are in line with the research of Ilham Thaief, Aris Baharudin, Priyono \& Mohamad Syafi'i Idrus (2015) with the title "Effects of Training, Compensation on Employee Work Performance". which states work discipline (X2) has a significant positive effect on employee performance (Y).

Hasil penelitiaan ini menolak dengan penelitiaan Ananta Dwikristianto Satedjo dan Sesilya Kempa (2015) dengan judul "pengaruh kompensansi dan displin kerja terhadap kinerja PT. Modern widya tehnical cabang jayapura" yang menyatakan bahwa displin kerja $\left(\mathrm{X}_{1}\right)$ tidak berpengaruh negatif terhadap kinerja karyawan (Y) .

\subsubsection{Pengaruh Kompensansi dan displin kerja terhadap kinerja karyawan}

Berdasarkan hasil penelitian dan pengolahan data mentah yang dilakukan Pada PT.(SBS) Sinar Bengkulu Selatan melalui penyebaran kuesoner terhadap 95 orang responden yang telah diuji sehingga dapat diketahui pengaruh kompensansi 
dan displin kerja Terhadap Kinerja Karyawan pada Pada PT.(SBS) Sinar Bengkulu Selatan

Kompensasi $\mathrm{X}_{1}$ dan Disiplin Kerja $\mathrm{X}_{2}$ memiliki pengaruh terhadap Kinerja Karyawan (Y), hal ini terlihat pada uji $\mathrm{F}$ yang menyatakan nilai $\mathrm{F}_{\text {hitung }}>\mathrm{F}_{\text {tabel }}$, yaitu yaitu $(50.091>1.9855)$ dan $(\operatorname{sig} \alpha=0.000<0,050)$, maka dengan demikian dapat disimpulkan bahwa $\mathrm{H}_{3}$ diterima artinya secara bersamaan variabel Kompensasi $\left(\mathrm{X}_{1}\right)$ dan Disiplin Kerja $\left(\mathrm{X}_{2}\right)$ memiliki pengaruh yang signifikan terhadap Kinerja Karyawan (Y) di Pada PT.(SBS) Sinar Bengkulu Selatan.

Hasil penelitian ini sejalan dengan penelitiaan Andi Armansyah, Idris Azis, Niluh Putuh Evvy Rosssanty, (2018) dengan judul "pengaruh kompensanssi dan dsiplin kerja terhadap kinerja karyawan pada pegawai kantor BPJS kesehatan cabang palu", menyatakan bahwa secara simultan kompensansi $\left(\mathrm{X}_{1}\right)$ dan displin kerja berpengaruh positif dan signifikan terhadap kinerja karyawan (Y).

Hasil penelitian ini sejalan dengan penelitian Putu Agus Candra Mahardika, Wayan Bagia, Ni Nyoman Yulianthini (2016), dengan judul "pengaruh kompensansi dan displin kerja terhadap kinerja karyawan pada hotel puri bagus lovina" menyatakan bahwa secara simultan kompensansi $\left(\mathrm{X}_{1}\right)$ dan displin kerja $\left(\mathrm{X}_{2}\right)$ berpengaruh positif dan signifikan terhadap variable kinerja karyawan (Y).

Hasil penelitian ini sejalan dengan penelitian Dina Kurniati (2018), dengan judul “pengaruh kompensansi dan displin kerja terhadap kinerja karyawan di pt. Marinal indopirma desa kapedi sumenep menyatakan bahwa secara simultan kompensansi $\left(\mathrm{X}_{1}\right)$ displin kerja $\left(\mathrm{X}_{2}\right)$ berpengaruh positif dan signifikan terhadap kinerja karyawan (Y). 


\section{BAB V \\ KESIMPULAN DAN SARAN}

\subsection{Kesimpulan}

Berdasarkan hasil penelitian yang telah dilakukan tentang pengaruh

Kompensasi dan Disiplin Kerja Terhadap Kinerja Karyawan pada Pada PT.(SBS)

Sinar Bengkulu Selatan, dapat disimpulkan sebagai berikut :

1. Kompensasi berpengaruh signifikan terhadap Kinerja Karyawan pada Pada PT.(SBS) Sinar Bengkulu Selatan.

2. Disiplin Kerja berpengaruh signifikan terhadap Kinerja Karyawan pada Pada PT.(SBS) Sinar Bengkulu Selatan.

3. Kompensasi $\left(X_{1}\right)$ dan Disiplin Kerja $\left(X_{2}\right)$ secara bersama-sama berpengaruh secara signifikan terhadap Kinerja Karyawan (Y) pada Pada PT.(SBS) Sinar Bengkulu Selatan.

\subsection{Saran}

Berdasarkan hasil penelitian, pembahasan dan kesimpulan yang diperoleh, maka saran yang dapat diberikan sebagai berikut :

1. Hasil penelitian menunjukan adanya pengaruh yang signifikan antara variabel Kompensasi $\left(\mathrm{X}_{1}\right)$ dan Disiplin Kerja $\left(\mathrm{X}_{2}\right)$ terhadap Kinerja Karyawan $(\mathrm{Y})$ Pada Pada PT.(SBS) Sinar Bengkulu Selatan, variabel Kompensasi memiliki ratarata terendah yaitu 3.55. Disarankan untuk lebih baiknya perlu ditingkatkan lagi Kompensasi, seperti perbanyak THR dan Insentif lembur yang lebih baik 
agar dapat meningkatkan Kinerja Karyawan pada Pada PT.(SBS) Sinar Bengkulu Selatan.

2. Hasil penelitian terlihat bahwa pada variabel Disiplin Kerja memiliki tanggapan responden yang terendah yaitu 3.49 dikarenakan pengusaha kurang memperhatikan apa yang dibutuhkan oleh pelanggan dalam menawarkan produk yang tersedia. Disarankan sebaiknya para pemilik dapat lebih aktip dalam mencari dan memahami apa yang diinginkan oleh konsumen agar dapat meningkatkan Kinerja Karyawan yang lebih efektif.

3. Hasil penelitian terlihat bahwa pada variabel Kompensasi, dan Disiplin Kerja memiliki tanggapan responden yang terendah yaitu 3,53 dikarenakan para pengusaha kurang melakukan kegiatan-kegiatan yang dapat merangsang minat Konsumen seperti melakukan kegiatan yang mendukung kinerja pemasaran yang ada didalam toko terutama Kompensasi, kualitas produk serta pelayanan yang lebih memuaskan. Disarankan pengusaha dapat memperkenalkan varian produk dan pola kelengkapan dengan melakukan acara rutin.

4. Disarankan bagi peneliti selanjutnya khususnya penelitian yang sama perlu dipertimbangkan untuk faktor-faktor lain diluar variabel Kompensasi dan Disiplin Kerja terhadap Kinerja Karyawan serta dapat meningkatkan penjualan pada perusahaan sehingga akan menghasilkan penelitian yang lebih baik. 


\section{DAFTAR PUSTAKA}

Anjani, R. (2019). Tata Kelola Adminitrasi Keuangan, Dan Pembangunan Desa Tepi Laut Kabupaten Bengkulu Utara. Jurnal Pengabdian Masyarakat Bumi Raflesia, 2 (2).

Asmawi, M. (2017). The effect of compensation, empowerment, and job satisfaction on employee loyalty. International Journal of Scientific Research and Management, 5(12), 7590-7599.

Ahmad Tohardi, 2002, Pemahaman Praktis Manajemen Sumber Daya Manusia, Universitas Tanjung Pura, Mandar Maju, Bandung.

Ananta Dwi Kristianto Satedjo dan Sesilia Kempa.2017. pengaruh kompensasi dan disiplin kerja terhadap kinerja karyawan di pt modern widya technical.Vol 5 no 3 (2017)

Andi Armansyah , Azis, Idris \& Rossanty, Evvy, Putu, Niluh (2018) "Pengaruh Kompensasi Dan Disiplin Kerja Terhadap Kinerja Pegawai Kantor BPJS Kesehatan Cabang Palu”. Jurnal Ilmu Manajemen Universitas Tadulako. $4(3) ; 235-244$

Any Isvandiari.2017. Pengaruh Kompensasi dan Disiplin Kerja Terhadap kinerja Karayawan PG.Meritjan, kediri, 2012. Jurnal JIBEKA, Vol.11 No.1 Agustus 2017.

Alex S. Nitisemito, 2014, Manajemen Personalia, Ghalia Indonesia, Jakarta

Ali Wairooy (2017), P Pengaruh Disiplin Kerja dan Kompensasi Terhadap Kinerja Karyawan". Jurnal Administrare: Jurnal Pemikiran Ilmiah dan Pendidikan Administrasi Perkantoran, Vol. 4, No. 1, 2017

Arikunto, S. 2010. Prosedur Penelitian Suatu Pendekatan Praktik. Jakarta: Rineka Cipta

Arikunto, Suharsimi. (2005). Manajemen Penelitian. Jakarta: RinekaCipta.

Budi, Setiyawan dan Waridin. 2006. Pengaruh Disiplin Kerja Karyawan dan Budaya Organisasi Terhadap Kinerja di Divisi Radiologi RSUP Dokter Kariadi, Semarang: JRBI. Vol 2. No 2. Hal: 181-198 
Baharuddin (2009)," Pengaruh Pelatihan, Kompensasi dan Disiplin Kerja Terhadap Prestasi Kerja Karyawan (Studi Pada Kantor PT. PLN (Persero) Area Pelayanan dan Jaringan Malang)". Profit (Jurnal Administrasi Bisnis), 6(2).

Brahmasari, Ida Ayu dan Agus Suprayetno. 2008. Pengaruh Motivasi Kerja, Kepemimpinan, dan Budaya Organisasi Terhadap Kepuasan Kerja Karyawan serta Dampaknya pada Kinerja Perusahaan (Studi kasus pada PT. Hei Hei International Wiratama Indonesia). Jurnal Manajemen dan Kewirausahaan. Vol. 10, September: 124-135.

Catherine Nathania. Skripsi. 2016. Pengaruh Kompensasi Terhadap Kinerja Karyawan Pada PT. Damai Motor Bandar Lampung

Davis, Keith. 1985. Perilaku Dalam Organisasi. Jakarta: Erlangga.

Dolet Unarandjan. 2003. Manajemen Displin. Jakarta: PT Gramedia Widiasarana Indonesia.

Danang Sunyoto, “Analisis Regresi dan Uji Hipotesis”, MedPress, Yogyakarta 2009.

Dina Kurniati, (2018),." Pengaruh Kompensasi Dan Disiplin Kerja Terhadap Kinerja Karyawan Di Pt. Marinal Indoprima Desa Kapedi Sumenep

Eddy Sutrisno, 2011, Manajemen Sumber Daya Manusia, Jakarta: Kencana

Firmandari, Nuraini. 2014. Pengaruh Kompensasi Terhadap Kinerja Karyawan Dengan Motivasi Kerja Sebagai Variabel Moderasi (Studi Kasus: Bank Syariah Mandiri Kantor Cabang Yogyakarta). Journal of Management and Sustainability. Vol 4 No.2.

Handoko, T. Hani. 2011. Manajemen Personalia dan Sumberdaya Manusia. Yogyakarta: Penerbit BPFE.

Heidjrachman dan Suad Husnan, Dr., M.B.A.,Manajemen Personalia, edisi kedua, penerbit BPFE - Yogyakarta, Yogyakarta 2002.

Hasibuan, Malayu S.P.. 2017. Manajemen Sumber Daya Manusia. Edisi Revisi. Jakarta: Bumi Aksara

Ilham Thaief, Aris Bhaharuddin, Priyono, Mohamad Syafi' I Idrus. 2015. Effect of Training, Compensation and Work Disciplin Against Employee Job Performance. Review of European Studies, vol 7 No. 11. (http:// eprints.binadarma.ac.id diakses pada tanggal 15 oktober 2017 ) 
Imam, Ghozali,. 2012. Aplikasi Analisis Multivariate Dengan Program IBM SPSS 20. Penerbit Universitas Diponegoro. Semarang

Keraf, Gorys. 2000. Diksi dan Gaya Bahasa. Jakarta: Rinneka Cipta.

Komang Edy Sukarta Wirya, 2019,.” The Effect of Compensation and Work Environment on Work Discipline and Performance of Mini Mart Employees in Denpasar City. http://ejournal.warmadewa.ac.id/index.php/jagaditha/article/view/605

Mangkunegara. (2010). Manajemen sumber daya manusia perusahaan. Bandung: PT Remaja Rosdakarya

Mangkuprawira, (2007) Manajemen Mutu Sumber Daya Manusia. Penerbit Ghalia Indonesia, Bogor

Mondy, Noe Robert M., 2011. Human Resource Management, Tenth Edition, Jilid I, Penterjemah Bayu Airlangga, M.M., Penerbit Erlangga, Jakarta.

Nazir, Moh. 2005. Metode Penelitian. Jakarta: Ghalia Indonesia

Onsardi, O. (2019). Effect Of Empowerment On Employees Performance (No. v7g9t). Center for Open Science.

Onsardi, O. (2019). Implementasi Manajemen Kinerja Di Universitas Muhammadiyah Bengkulu (No. kzyfx). Center for Open Science.

Onsardi, O. (2018). Loyalitas Karyawan pada Universitas Swasta di Kota Bengkulu. COSTING: Journal of Economic, Bussines and Accounting, 2(1), 1-13.

Onsardi, O. (2019). Implementasi Empowerment Dalam Meningkatkan Kinerja Karyawan (No. bgwju). Center for Open Science.

Onsardi, O. (2020). Manajemen Sumber Daya Manusia (No. yq85t). Center for Open Science.

Putu Agus Candra Mahardika, I Wayan Bagia, Ni Nyoman Yulianthini, 2016. Pengaruh Kompensasi Dan Disiplin Kerja Terhadap Kinerja Karyawan Pada Hotel Puri Bagus Lovina.Jurnal Bisma Vol. 4 Tahun 2016. 
Priyono , Suheriyatmono, (2016),.’'Influence Satisfaction, Compensation and Work Discipline the Employee Performance at PT. Lion Air in Batam. Journal / Review Of Eurupean Studiens / Archives / Vol.8, No.4 (2016).

Prasetyo. 2006. Metode Penelitian Kuantitatif : Teori dan Aplikasi. Raja Grafindo Persada : Jakarta.

Putri, S. H. (2020). Pengaruh Disiplin Kerja Dan Lingkungan Kerja Terhadap Kinerja Karyawan (No. tfbve). Center for Open Science.

Rivai, Veitzal., 2008, Manajemen Sumber Daya Manusia untuk Perusahaan: Dari Teori ke Praktik. Jakarta: PT.Rajagrafindo Persada

Robbins, P. Stephen. (2006). Perilaku Organisasi. Edisi Sepuluh. Diterjemahkan oleh: Drs. Benyamin Molan. Erlangga, Jakarta

Simamora, Henry, 2004, "Manajemen Sumber Daya Manusia”, Yogyakarta; STIE YKPN.

Sedarmayanti. (2015). Manajemen Sumber Daya Manusia, Reformasi Birokrasi, dan Manajemen Negeri Sipil. Bandung: Refika Aditama

Sevilla, 1994, Pengantar Metode Penelitian, Jakarta: Universitas Indonesia Press

Sekaran, 2006, Metodologi Penelitian untuk Bisnis, Edisi 4, Buku 1, Jakarta: Salemba Empat.

Suwondo, Diah Indriani., Sutanto, Addy Madiono. 2015. Hubungan Lingkungan Kerja, Disiplin Kerja dan Kinerja Karyawan. E- Jurnal, Vol. 3, No. 1, Januari 2015, Hal. 84-94Simamora, Henry. 2004. Manajemen Sumber Daya Manusia. Yogyakarta: STIE YKPN

Suprayetno (2009)," Pengaruh Pelatihan, Kompensasi dan Disiplin Kerja Terhadap Prestasi Kerja Karyawan (Studi Pada Kantor PT. PLN (Persero) Area Pelayanan dan Jaringan Malang)". Profit (Jurnal Administrasi Bisnis.

Suwati, Yuli (2013) "Pengaruh Kompensasi dan Motivasi Kerja terhadap Kinerja Karyawan PT. Tunas Hijau Samarinda”. eJournal Ilmu Administrasi Bisnis. I (1):41.55

Siagian. 2012. Manajemen Sumber Daya Manusia. Jakarta : Bumi Aksara Sugiyono. 2013. Metode Penelitian Manajemen. Bandung : Alfabeta 
Tangkilisan, H. N. S. (2005). Pengaruh Kompensasi Terhadap Motivasi Kerja Karyawan Bagian Personalia PT Agronesia Divisi Industri Makanan Dan Minuman Bandung. Universitas Widyatama

Tanjung, Bahdin Nur \& Ardial. 2005. Pedoman Penulisan Karya Ilmiah : (Proposal, Skripsi, danTesis) dan Mempersiapkan Diri Menjadi Penulis Artikel Ilmiah. Jakarta: Kencana.

Thoyib. 2005. Hubungan Kepemimpinan, Budaya, Strategi, dan Kinerja: Pendekatan Konsep. Jurnal. Staf Pengajar Fakultas Ekonomi Universitas Brawijaya Malang

Umar Husien. 2007, Metode Penelitian Untuk Skripsi Dan Tesis Bisnis, Jakarta: PT. Raja Grafindo Persada

Rivai,Veithzal 2008. Manajemen Sumber Daya Manusia untuk Perusahaan .PT.Raja Grafindo Persada: Jakarta

Werther, \& Keith Davis. 1996. Human Resources And Personal Management.Edisi kelima. New York: McGraw-Hill

Yayu, n.d (2005). Pengaruh Kompensasi Terhadap Motivasi Kerja Karyawan Bagian Personalia PT Agronesia Divisi Industri Makanan Dan Minuman Bandung. Universitas Widyatama

Yinawati, (2016),.” Pengaruh kompensansi terhadap kinerja karyawan”. Journal of Management and Sustainability. Vol 4 No.2 